\title{
Article \\ Structural Diversity of Silver Fluorinated $\beta$-Diketonates: Effect of the Terminal Substituent and Solvent
}

\author{
Evgeniia S. Vikulova ${ }^{1, *}$, Taisiya S. Sukhikh ${ }^{1}{ }^{\mathbb{D}}$, Sergey A. Gulyaev ${ }^{1,2}$, Igor Yu. Ilyin ${ }^{1}$ and Natalia B. Morozova ${ }^{1}$ \\ 1 Nikolaev Institute of Inorganic Chemistry, Siberian Branch of Russian Academy of Sciences, \\ 3, Academy Lavrentieva Avenue, 630090 Novosibirsk, Russia; sukhikh@niic.nsc.ru (T.S.S.); \\ s.gulyaev@g.nsu.ru (S.A.G.); ilyin@niic.nsc.ru (I.Y.I.); mor@niic.nsc.ru (N.B.M.) \\ 2 Department of Natural Sciences, Novosibirsk State University, 2 Pirogova Street, 630090 Novosibirsk, Russia \\ * Correspondence: lazorevka@mail.ru; Tel.: +7-383-3309556
}

Citation: Vikulova, E.S.; Sukhikh, T.S.; Gulyaev, S.A.; Ilyin, I.Y.;

Morozova, N.B. Structural Diversity of Silver Fluorinated $\beta$-Diketonates:

Effect of the Terminal Substituent and Solvent. Molecules 2022, 27, 677.

https://doi.org/10.3390/

molecules 27030677

Academic Editor: Massimiliano Arca

Received: 30 December 2021

Accepted: 17 January 2022

Published: 20 January 2022

Publisher's Note: MDPI stays neutral with regard to jurisdictional claims in published maps and institutional affiliations.

Copyright: (C) 2022 by the authors. Licensee MDPI, Basel, Switzerland. This article is an open access article distributed under the terms and conditions of the Creative Commons Attribution (CC BY) license (https:// creativecommons.org/licenses/by/ $4.0 /)$.

\begin{abstract}
In order to demonstrate the role of the fluorination and some solvents in the structural organization of the $\mathrm{Ag}(\mathrm{I})$ coordination polymers with $\beta$-diketonate ligands $\left(\mathrm{R}^{1} \mathrm{C}(\mathrm{O}) \mathrm{C}_{\alpha} \mathrm{HC}(\mathrm{O}) \mathrm{R}^{2}\right)^{-}$we synthesized a series of the compounds containing tfac- $\left(\mathrm{R}_{1}=\mathrm{CH}_{3}, \mathrm{R}^{2}=\mathrm{CF}_{3}\right)$ and pfpac- $\left(\mathrm{R}_{1}=\mathrm{CH}_{3}\right.$, $\left.\mathrm{R}^{2}=\mathrm{C}_{2} \mathrm{~F}_{5}\right)$ anions. Solvent-free $[\mathrm{Ag}(\mathrm{L})]_{\infty}(\mathrm{L}=\mathrm{tfac} \mathbf{1}$, pfpac 2$)$ compounds and the corresponding acetonitrile and toluene adducts have been characterized by elemental analysis and/or NMR, IR and single-crystal XRD. This series includes five new coordination polymers. Compound $\mathbf{1}$ is a $3 \mathrm{D}$ coordination framework based on $\mathrm{Ag}-\mathrm{O}_{\text {chelate/bridge, }} \mathrm{Ag}-\mathrm{C}_{\alpha}$ bonds, and argentophilic interactions An increase in the fluorinated group leads to a chain coordination polymer $\mathbf{2}$ of an unusual structural organization. These chains can be represented as a "DNA-type", where two intertwined helices based on $\mathrm{Ag}-\mathrm{O}_{\text {chelate }}$ and $\mathrm{Ag}-\mathrm{C}_{\alpha}$ bonds are connected through $\mathrm{Ag}-\mathrm{O}_{\text {bridge }}$ ones. Two structural types of chain coordination polymers, $\left[\mathrm{Ag}(\mathrm{tfac})\left(\mathrm{CH}_{3} \mathrm{CN}\right)\right]$ and $\left[\mathrm{Ag}_{2}(\mathrm{~L})_{2}\right.$ (solvent)], have been revealed for the adducts. The latter structural type differs significantly from the previously studied toluene and acetonitrile adducts of fluorinated $\mathrm{Ag}(\mathrm{I}) \beta$-diketonates of the same stoichiometry. Thermal analysis in helium showed that both $\mathbf{1}$ and $\mathbf{2}$ decompose to metallic silver with the compound of pfpac-ligand being slightly more stable.
\end{abstract}

Keywords: silver; $\beta$-diketonate; fluorinated; coordination polymers; crystal structure; TGA

\section{Introduction}

$\beta$-Diketonate ligands $\left(\mathrm{R}^{1} \mathrm{C}(\mathrm{O}) \mathrm{C}_{\alpha} \mathrm{RC}(\mathrm{O}) \mathrm{R}^{2}\right)^{-}$are widely demanded building blocks in coordination chemistry, which are distinguished by a chelating effect and internal conjugation, providing stability, and their great structural versatility by their varying terminal groups $\left(R^{1}\right.$ and $\left.R^{2}\right)$ and the substituent at the methine carbon atom $\left(C_{\alpha}\right)[1-4]$. This allows the forming of complexes of various structural organization and dimension. In particular, for silver, fluorinated $\beta$-diketonate ligands were used for constructing coordination polymers with macroligands $[5,6]$ or exo-N-donor synthons $[7,8]$, stabilizing the multinuclear ethynide or thiolate clusters [9-11], and obtaining polymer, di- or mononuclear precursors [12-14] for chemical vapor deposition processes.

However, much less attention has been paid to the scrutiny of pristine silver(I) fluorinated $\beta$-diketonates, although a rich structural diversity can also be expected there. In addition to the different modes of anion coordination, a feature of silver in such a ligand environment includes the $\mathrm{Ag}-\mathrm{C}_{\alpha}$ bonds with the methine carbon atom and argentophilic interactions.

The realization of these possibilities is determined by the structure of the $\beta$-diketonate ligand. Several silver (I) $\beta$-diketonates have been structurally characterized, where only the influence of the non-fluorinated terminal group can be observed: $R=H, R^{1}=C F_{3}$, $\mathrm{R}^{2}=\mathrm{CH}_{3}$ [15], $\mathrm{C}\left(\mathrm{CH}_{3}\right)_{3}$ [16], $\mathrm{C}\left(\mathrm{OCH}_{3}\right)\left(\mathrm{CH}_{3}\right)_{2}$ [17], $\mathrm{C}_{6} \mathrm{H}_{5}$ [18] (Scheme 1). In particular, an increase in the substituent reduces the dimensionality of the polymer structure to $1 \mathrm{D}$. These 
tapes are corrugated, and for the tert-butyl and phenyl substituents, they are organized in the same way, with a with significant kink of the chelate metallocycle $[16,18]$, while an additional donor atom $\left(\mathrm{O}_{\mathrm{CH} 3}\right)$, which is coordinated to silver, reduces the tightness of the structure [17]. The effects of changing the substituent at the methine atom or fluorinated group have not been studied.<smiles>CC(=O)C=C(C)C(=O)C(F)(F)F</smiles><smiles>CC(=O)C=C(C(=O)C(F)F)C(F)F</smiles><smiles>CC(C)(C)C(O)(C=C(O)C(F)(F)F)C(=O)C(=O)C(=O)C(F)(F)F</smiles><smiles>COC(C)(C)C(=O)C=C(C(=O)F)C(F)(F)F</smiles><smiles>O=C(O)C(=O)C(=O)c1cccs1</smiles>

Scheme 1. The $\beta$-diketonate ligands discussed in this work.

Another interesting capacity to design the structure of silver(I) $\beta$-diketonates is the coordination of solvents of a different nature. For example, coordination polymers $\left[\mathrm{Ag}_{2}\left(\mathrm{R}^{1} \mathrm{C}(\mathrm{O}) \mathrm{C}_{\alpha} \mathrm{HC}(\mathrm{O}) \mathrm{R}^{2}\right)_{2} \mathrm{Q}\right]_{\infty}$ are known for $\mathrm{Q}=$ water [19], toluene, tetrahydrofuran (THF) [20] $\left(\mathrm{R}^{1}=\mathrm{R}^{2}=\mathrm{CF}_{3}\right)$, and acetonitrile [21] $\left(\mathrm{R}^{1}=\mathrm{CF}_{3}, \mathrm{R}^{2}=\mathrm{C}_{6} \mathrm{H}_{5}, \mathrm{C}_{10} \mathrm{H}_{7}, \mathrm{C}_{4} \mathrm{H}_{3} \mathrm{~S}\right)$ (Scheme 1). Despite the same stoichiometry, the structures of these polymers differ in their dimensions (2D for water and toluene adducts, 1D for THF and acetonitrile adducts) and further in their $\beta$-diketonate coordination modes and silver environment.

In addition to the fundamental interest for the structural features and the development of an understanding of the silver coordination capabilities, $\mathrm{Ag}(\mathrm{I}) \beta$-diketonates and their adducts with solvents are also useful for practical applications. For example, some polymers have exhibited solid phase luminescence [21]. Due to their low thermal stability $\left(<200{ }^{\circ} \mathrm{C}\right)$, these compounds can be used to obtain Ag-based coatings and nanoparticles by thermal or supercritical fluid deposition $[15,22,23]$. The decomposition temperature range and solubility of the target solvent can be tuned by a ligand structure modification. Moreover, photosensitivity of silver $\beta$-diketonates makes it possible to obtain functional materials even at room temperature [22,24]. In addition, pristine silver(I) coordination polymers are receiving attention as antimicrobial materials [25-27].

Summarizing the above, our work is devoted to revealing the effect of a fluorinated substituent $\left(\mathrm{CF}_{3} \rightarrow \mathrm{C}_{2} \mathrm{~F}_{5}\right)$ and a solvent $\left(\mathrm{CH}_{3} \mathrm{CN}\right.$, toluene) on the structural and thermal properties of $\mathrm{Ag}(\mathrm{I}) \beta$-diketonates (Scheme 1). All the complexes with 1,1,1,2,2-pentafluoro-3,5-hexanedione (Hpfpac, $\mathrm{C}_{2} \mathrm{~F}_{5} \mathrm{C}(\mathrm{O}) \mathrm{CH}_{2} \mathrm{C}(\mathrm{O}) \mathrm{CH}_{3}$ ) have been synthesized for the first time. For the counterpart, 1,1,1-trifluoro-2,4-pentanedione $\left(\mathrm{Htfac}, \mathrm{CF}_{3} \mathrm{C}(\mathrm{O}) \mathrm{CH}_{2} \mathrm{C}(\mathrm{O}) \mathrm{CH}_{3}\right)$, some information on the silver complex has been already presented [15], however, without any data on the discussed adducts. In addition, despite the description of the $[\mathrm{Ag}(\mathrm{tfac})]_{\infty}$ structure [15], no corresponding data are available in the Cambridge Structural Database. Thus, here we present the synthesis and characterization of the $\mathrm{Ag}(\mathrm{I})$ fluorinated $\beta$-diketonate coordination polymers and their solvent adducts, the crystal structures of $[\mathrm{Ag}(\mathrm{L})]_{\infty}(\mathrm{L}=\operatorname{tfac} 1$, pfpac 2$)$, $\left[\mathrm{Ag}(\mathrm{tfac})\left(\mathrm{CH}_{3} \mathrm{CN}\right)\right]_{\infty} \mathbf{1 a},\left[\mathrm{Ag}_{2}(\text { pfpac })_{2}\left(\mathrm{CH}_{3} \mathrm{CN}\right)\right]_{\infty} \mathbf{2 a},\left[\mathrm{Ag}_{2}(\mathrm{~L})_{2}\left(\mathrm{C}_{7} \mathrm{H}_{8}\right)\right]_{\infty}(\mathrm{L}=$ tfac $\mathbf{1 t}$, pfpac $\mathbf{2 t})$, and the comparative thermogravimetric study. The features of the new structures versus the related coordination polymers $[20,21]$ will be also discussed. 


\section{Materials and Methods}

\subsection{Sourses and Analitical Methods}

All reagents and solvents were commercially available. For synthesis under ambient conditions no additional purification was performed. For synthesis under the inert conditions (Schlenk technique), all the liquids were previously dehydrated and then degassed by distillation in argon.

Elemental analyses were performed with a Carlo Erba Model 1106 instrument (for C, $\mathrm{H}, \mathrm{N}$ ) or by a standard spectrophotometric method with La complex of alizarin complexone (for F) [28]. The errors of the measurements did not exceed 0.5 abs. wt.\%.

IR (infrared) spectra were recorded with a Scimitar FTS 2000 spectrometer in the wavenumber range of $4000-400 \mathrm{~cm}^{-1}$. The samples were pellets with $\mathrm{KBr}$ or fluorinated oil.

NMR (nuclear magnetic resonance) spectra were recorded on a Bruker Avance 500 Plus spectrometer $\left({ }^{1} \mathrm{H}\right.$ : $\left.500.129 \mathrm{MHz}, 13 \mathrm{C}: 125.757 \mathrm{MHz}\right)$ at $25^{\circ} \mathrm{C}$. The samples were dissolved in deuterated dimethylsulfoxide (DMSO- $\left.d_{6}\right)$. Chemical shifts $(\delta, \mathrm{ppm})$ were calibrated with residual DMSO as the internal standard $\left({ }^{1} \mathrm{H}=2.50 ;{ }^{13} \mathrm{C}=39.52\right)$ [29].

The thermogravimetry (TG) study was carried out with a Netzsch TG 209 F1 Iris thermobalance in a helium flow $\left(30 \mathrm{~mL} \mathrm{~min}^{-1}\right)$. Sample masses were $10 \pm 1 \mathrm{mg}$; the heating rate was $10^{\circ} \mathrm{C} \cdot \mathrm{min}^{-1}$. The thermal effects were recorded with $\mathrm{c}-\mathrm{DTA}{ }^{\circledR}$ software (Netzsch) for the calculated signal of differential thermal analysis (c-DTA). The final decomposition products were studied by X-ray powder diffraction (XRPD), with a Shimadzu XRD-7000 diffractometer (Tokyo, Japan) using $\mathrm{CuK} \alpha$ radiation (Ni filter, OneSight linear detector). The steps of $2 \Theta$ were $0.0143^{\circ}$ with an accumulation of $5 \mathrm{sec}$ at a point in the range $10-65^{\circ}$.

\subsection{Synthesis of $[A g(t f a c)]_{\infty} \mathbf{1}$}

The synthesis was carried out in air. $0.222 \mathrm{~g}$ of $\mathrm{Ag}_{2} \mathrm{O}(0.96 \mathrm{mmol})$ was placed in aluminum foil-wrapped flask, and then $35 \mathrm{~mL}$ of $\mathrm{Et}_{2} \mathrm{O}$ was added. The flask was then placed in water/ice bath for cooling. $0.4 \mathrm{~mL}$ of Htfac $(2.10 \mathrm{mmol})$ was added dropwise with stirring. Synthesis continued for $2 \mathrm{~h}$. White precipitate that appeared was filtered and dried in vacuum. The product was $\mathrm{Ag}_{2}(\mathrm{tfac})_{2}\left(\mathrm{H}_{2} \mathrm{O}\right)$ 1w. Yield: $90 \%(0.468 \mathrm{~g}, 0.87 \mathrm{mmol})$. IR spectrum $\left(\mathrm{KBr}, \mathrm{cm}^{-1}\right):$ 3430, $3266(v(\mathrm{O}-\mathrm{H})), 3011,2929,2862(v(\mathrm{C}-\mathrm{H})), 1655,1621,1552(v(\mathrm{C}=\mathrm{O})), 1528$ $(v(\mathrm{C}=\mathrm{C})+\delta(\mathrm{C}-\mathrm{H})), 1512(v(\mathrm{C}=\mathrm{O})+v(\mathrm{C}=\mathrm{C})), 1481(v(\mathrm{C}=\mathrm{O})), 1438\left(\delta\left(\mathrm{CH}_{3}\right)\right), 1360(v(\mathrm{C}=\mathrm{O}))$, $1282\left(v(\mathrm{C}=\mathrm{C})+v\left(\mathrm{C}-\mathrm{CF}_{3}\right)\right), 1215(\delta(\mathrm{CH})), 1190(v(\mathrm{C}-\mathrm{F})), 1132(v(\mathrm{C}-\mathrm{C})), 1119\left(\delta\left(\mathrm{CF}_{3}\right)\right), 1021$, $1000\left(\rho\left(\mathrm{CH}_{3}\right)\right), 929,847\left(v\left(\mathrm{C}-\mathrm{CF}_{3}\right)\right), 808-800\left(v(\mathrm{C}-\mathrm{C})+\delta(\mathrm{C}-\mathrm{C})+v\left(\mathrm{C}-\mathrm{CH}_{3}\right)+\pi(\mathrm{C}-\mathrm{H})\right), 758$ $\left(v(\mathrm{Ag}-\mathrm{O})+v\left(\mathrm{C}-\mathrm{CH}_{3}\right)+\right.$ chelate def. $), 725\left(v(\mathrm{Ag}-\mathrm{C})+v\left(\mathrm{C}-\mathrm{CH}_{3}\right)+\delta(\mathrm{C}=\mathrm{O})\right), 604(v(\mathrm{Ag}-\mathrm{O}))$, $551(v(\mathrm{Ag}-\mathrm{C})), 516(v(\mathrm{Ag}-\mathrm{C}))$.

The slow ether extraction of $\mathbf{1 w}$ in an evacuated sealed two-knee ampoule [30] leads to the crystals of the anhydrous $[\mathrm{Ag}(\mathrm{tfac})]_{\infty} \mathbf{1}$, suitable for single-crystal X-ray diffraction (XRD) in the lower knee. The partial decomposition of $\mathbf{1} \mathbf{w}$ was also observed in the upper knee. Anal. Calcd. (wt. \%): for $\mathrm{Ag}_{2} \mathrm{C}_{10} \mathrm{H}_{10} \mathrm{O}_{5} \mathrm{~F}_{6}$ 1: C, 23.0; $\mathrm{H}, 1.5 ; \mathrm{F}, 21.8$. Found: C, 22.9; H, 1.8; F, 22.0. IR spectrum $\left(\mathrm{KBr}, \mathrm{cm}^{-1}\right): 2923(v(\mathrm{C}-\mathrm{H})), 1635(v(\mathrm{C}=\mathrm{O})$, $1532(v(\mathrm{C}=\mathrm{C})+\delta(\mathrm{C}-\mathrm{H})), 1463(v(\mathrm{C}=\mathrm{O})), 1360(v(\mathrm{C}=\mathrm{O})), 1281\left(v(\mathrm{C}=\mathrm{C})+v\left(\mathrm{C}-\mathrm{CF}_{3}\right)\right), 1203$ $(\delta(\mathrm{CH})), 1189(v(\mathrm{C}-\mathrm{F})), 1137(v(\mathrm{C}-\mathrm{C})), 1117\left(\delta\left(\mathrm{CF}_{3}\right)\right), 1020,988\left(\rho\left(\mathrm{CH}_{3}\right)\right), 919,844\left(v\left(\mathrm{C}-\mathrm{CF}_{3}\right)\right)$, $816\left(v(\mathrm{C}-\mathrm{C})+\delta(\mathrm{C}-\mathrm{C})+v\left(\mathrm{C}-\mathrm{CH}_{3}\right)\right), 803(\pi(\mathrm{C}-\mathrm{H})), 757\left(v(\mathrm{Ag}-\mathrm{O})+v\left(\mathrm{C}-\mathrm{CH}_{3}\right)+\right.$ chelate def. $)$, $724\left(v(\mathrm{Ag}-\mathrm{C})+v\left(\mathrm{C}-\mathrm{CH}_{3}\right)+\delta(\mathrm{C}=\mathrm{O})\right), 603(v(\mathrm{Ag}-\mathrm{O})), 555(v(\mathrm{Ag}-\mathrm{C})), 517(v(\mathrm{Ag}-\mathrm{C}))$.

\subsection{Synthesis of $[A g(p f p a c)]_{\infty} 2$}

The synthesis in air was performed similarly for 1w; however, the solvent volume was reduced to prevent product dissolution. Namely, for $0.190 \mathrm{~g}$ of $\mathrm{Ag}_{2} \mathrm{O}(0.82 \mathrm{mmol})$ we used $6.5 \mathrm{~mL}$ of $\mathrm{Et}_{2} \mathrm{O}$ and $0.3 \mathrm{~mL}$ of Hpfpac $(1.98 \mathrm{mmol})$. Resulting white precipitate was filtered and dried in vacuum. The product was also agua- $\beta$-diketonate $\mathrm{Ag}_{2}(\mathrm{pfpac})_{2}\left(\mathrm{H}_{2} \mathrm{O}\right) 2 \mathbf{2}$. Yield: 82\% (0.430 g, $0.67 \mathrm{mmol}$ ). Anal. Calcd. (wt. \%): for $\mathrm{Ag}_{2} \mathrm{C}_{12} \mathrm{H}_{10} \mathrm{O}_{5} \mathrm{~F}_{10}$ 2w: C, 22.5; $\mathrm{H}, 1.6 ; \mathrm{F}, 29.7$. Found: C, 22.9; H, 1.1; F, 30.3. IR spectrum $\left(\mathrm{KBr}, \mathrm{cm}^{-1}\right): 3430,3272(v(\mathrm{O}-\mathrm{H}))$, 2980, $2933(v(\mathrm{C}-\mathrm{H})), 1645(v(\mathrm{C}=\mathrm{O}), 1518(v(\mathrm{C}=\mathrm{C})+\delta(\mathrm{C}-\mathrm{H})+v(\mathrm{C}=\mathrm{O})), 1459(v(\mathrm{C}=\mathrm{O}))$, $1360(v(\mathrm{C}=\mathrm{O})), 1328\left(v\left(\mathrm{C}-\mathrm{CF}_{3}\right)\right), 1214(\delta(\mathrm{CH})), 1192(v(\mathrm{C}-\mathrm{F})), 1162(v(\mathrm{C}-\mathrm{C})), 1123\left(\delta\left(\mathrm{CF}_{3}\right)\right)$, 
1027, $992\left(\rho\left(\mathrm{CH}_{3}\right)\right), 932\left(v\left(\mathrm{C}-\mathrm{CF}_{3}\right)\right), 819\left(v(\mathrm{C}-\mathrm{C})+\delta(\mathrm{C}-\mathrm{C})+v\left(\mathrm{C}-\mathrm{CH}_{3}\right)\right), 805(\pi(\mathrm{C}-\mathrm{H})), 757$ $\left(v(\mathrm{Ag}-\mathrm{O})+v\left(\mathrm{C}-\mathrm{CH}_{3}\right)+\right.$ chelate def. $), 726\left(v(\mathrm{Ag}-\mathrm{C})+v\left(\mathrm{C}-\mathrm{CH}_{3}\right)+\delta(\mathrm{C}=\mathrm{O})\right), 620(v(\mathrm{Ag}-\mathrm{O}))$, $561(v($ Ag-C $)), 531(v($ Ag-C $)), 496$.

To obtain the anhydrous compound, we carried out a similar synthesis in a Schlenk apparatus using molecular sieves. The volume of ether here was such as to ensure complete dissolution of the target product (e.g., $30 \mathrm{~mL}$ for $56 \mathrm{mg}$ of $\mathrm{Ag}_{2} \mathrm{O}$ ). After $18 \mathrm{~h}$ stirring at room temperature, the reaction mixture was filtered using kieselguhr. A white powder $[\mathrm{Ag}(\mathrm{pfpac})]_{\infty} 2$ was obtained from a colorless mother liquor by evaporation of ether in vacuum $\left(10^{-2}\right.$ Torr). ${ }^{1} \mathrm{H}$ NMR spectrum (DMSO- $\left.d_{6}, 2.50 \mathrm{ppm}\right): \delta 5.02$ (br s, $\left.1 \mathrm{H}, \mathrm{C}_{\alpha}-\mathrm{H}\right)$, 1.96 (s, 3H, -CH3). ${ }^{13} \mathrm{C}$ NMR spectrum (DMSO-d $\left.d_{6}, 39.52 \mathrm{ppm}\right): 194.78$ (s, C=O, pfpac), $169.00\left(\mathrm{t}, J_{\mathrm{C}, \mathrm{F}}=20.7 \mathrm{~Hz}, \mathrm{C}=\mathrm{O}\right.$, pfpac), 118.97 (qt, $\left.J_{1}=286.4, J_{2}=37.0,-\mathrm{CF}_{3}, \mathrm{pfpac}\right), 108.80$ (tq, $J_{1}=264.0, J_{2}=35.7,>\mathrm{CF}_{2}$, pfpac), 91.79 (s, $\mathrm{C}_{\alpha}-\mathrm{H}$, pfpac), 29.95 (s, $-\mathrm{CH}_{3}$, pfpac).

Crystals of the anhydrous compound 2 suitable for single-crystal XRD were also grown by slow ether extraction of $\mathbf{2} \mathbf{w}$ in an evacuated sealed two-knee ampoule. As for the tfac-based complex, the partial decomposition of the initial $\mathbf{2} \mathbf{w}$ was observed in the upper knee.

\subsection{Synthesis of $A g(I) \beta$-Diketonate Adducts}

Adducts with acetonitrile and toluene were obtained by recrystallization of $\operatorname{Ag}(\mathrm{I})$ aqua- $\beta$-diketonates $\mathbf{1 w}$ and $\mathbf{2 w}$ from the corresponding solvents under ambient conditions. The resulting solution was filtered to remove a small amount of brown precipitate, and then the solvent was evaporated in vacuum $\left(10^{-1}-10^{-2}\right.$ Torr $)$. The products were formed as white powders and corresponded to stoichiometry $\left[\mathrm{Ag}_{2}(\mathrm{~L})_{2} \mathrm{Q}\right]_{\infty}\left(\mathrm{Q}=\mathrm{CH}_{3} \mathrm{CN}\right.$, toluene; $\mathrm{L}=\mathrm{tfac}$, pfpac). The yields were $90-95 \%$ for acetonitrile and $80 \%$ for toluene.

$\mathrm{Ag}_{2}(\mathrm{tfac})_{2}\left(\mathrm{CH}_{3} \mathrm{CN}\right),{ }^{1} \mathrm{H}$ NMR spectrum (DMSO-d $\left.6,2.50 \mathrm{ppm}\right): \delta 5.14$ (br s, $\left.1 \mathrm{H}, \mathrm{C}_{\alpha}-\mathrm{H}\right)$, $2.07\left(\mathrm{~s},(3 \mathrm{H}) \times 0.5,-\mathrm{CH}_{3}, \mathrm{CH}_{3} \mathrm{CN}\right), 1.98\left(\mathrm{~s}, 3 \mathrm{H},-\mathrm{CH}_{3}, \mathrm{tfac}\right)$.

$\left[\mathrm{Ag}_{2}(\mathrm{tfac})_{2}\left(\mathrm{C}_{7} \mathrm{H}_{8}\right)\right]_{\infty} \mathbf{1 t},{ }^{1} \mathrm{H}$ NMR spectrum $\left(\mathrm{DMSO}-d_{6}, 2.50 \mathrm{ppm}\right): \delta 7.25$ and 7.18 (both $\mathrm{m},(5 \mathrm{H}) \times 0.5, \mathrm{C}(\mathrm{Ph})-\mathrm{H}$, toluene), 5.05 (br s, 1H, $\left.\mathrm{C}_{\alpha}-\mathrm{H}\right), 2.30\left(\mathrm{~s},(3 \mathrm{H}) \times 0.5,-\mathrm{CH}_{3}\right.$, toluene), $2.01\left(\mathrm{~s}, 3 \mathrm{H},-\mathrm{CH}_{3}, \mathrm{tfac}\right)$.

$\left[\mathrm{Ag}_{2}(\mathrm{pfpac})_{2}\left(\mathrm{CH}_{3} \mathrm{CN}\right)\right]_{\infty} \mathbf{2 a},{ }^{1} \mathrm{H}$ NMR spectrum (DMSO- $\left.d_{6}, 2.50 \mathrm{ppm}\right): \delta 5.06$ (br s, $1 \mathrm{H}$, $\left.\mathrm{C}_{\alpha}-\mathrm{H}\right), 2.07\left(\mathrm{~s},(3 \mathrm{H}) \times 0.5,-\mathrm{CH}_{3}, \mathrm{CH}_{3} \mathrm{CN}\right), 2.02\left(\mathrm{~s}, 3 \mathrm{H},-\mathrm{CH}_{3}\right.$, pfpac).

$\left[\mathrm{Ag}_{2}(\text { pfpac })_{2}\left(\mathrm{C}_{7} \mathrm{H}_{8}\right)\right]_{\infty} \mathbf{2 t},{ }^{1} \mathrm{H}$ NMR spectrum (DMSO-d $\left.d_{6}, 2.50 \mathrm{ppm}\right): \delta 7.25$ and 7.18 (both $\mathrm{m},(5 \mathrm{H}) \times 0.5, \mathrm{C}(\mathrm{Ph})-\mathrm{H}$, toluene), $5.13\left(\right.$ br s, $\left.1 \mathrm{H}, \mathrm{C}_{\alpha}-\mathrm{H}\right), 2.30\left(\mathrm{~s},(3 \mathrm{H}) \times 0.5,-\mathrm{CH}_{3}\right.$, toluene), 2.00 (s, 3H, $-\mathrm{CH}_{3}$, pfpac).

The crystals of the adducts suitable for single-crystal XRD were obtained by slow evaporation of the corresponding solvents at $5{ }^{\circ} \mathrm{C}$. For all adducts, the stoichiometry of the crystals corresponded to powder samples, except with $\left[\mathrm{Ag}(\mathrm{tfac})\left(\mathrm{CH}_{3} \mathrm{CN}\right)\right]_{\infty} \mathbf{1 a}$.

\subsection{Single-Crystal XRD Study}

Single-crystal XRD data for compounds 1, 1a and 1t (Table S1, Supplementary Materials) were collected by a Bruker D8 Venture diffractometer with a CMOS PHOTON III detector and $\mathrm{I} \mu \mathrm{S} 3.0$ microfocus source (collimating Montel mirrors). For compounds 2, 2a and $\mathbf{2 t}$ (Table S1, Supplementary Materials), the data collection was performed on a Bruker Apex DUO diffractometer equipped with a $4 \mathrm{~K}$ CCD area detector using the graphite-monochromated radiation. All the experiments were carried at $150 \mathrm{~K}$ using $\mathrm{MoK}_{\alpha}$ radiation $(\lambda=0.71073 \AA)$. The $\varphi$ - and $\omega$-scan techniques were employed to measure intensities. Absorption corrections were applied with the use of the SADABS program. The crystal structures were solved using the SHELXT [31] and were refined using SHELXL [32] programs with OLEX2 GUI [33]. Atomic displacement parameters for nonhydrogen atoms were refined anisotropically except for $\mathrm{C}$ atoms in 2 . The structures were deposited to the Cambridge Crystallographic Data Centre (CCDC) as a supplementary publication No. 2131021-2131026. 


\section{Results and Discussion}

\subsection{Synthesis and Characterization}

The syntheses of both $\mathrm{Ag}(\mathrm{I})$ fluorinated $\beta$-diketonates were performed by a convenient acid-base reaction between silver oxide and the corresponded $\beta$-diketone $[6,15-17,19]$. The reactions were carried out at ambient conditions using diethyl ether as a solvent. The generated water (half-equivalent, Scheme 2) tends to be incorporated into the resulting compound. The aqua- $\beta$-diketonates of $\mathrm{Ag}_{2}(\mathrm{~L})_{2}\left(\mathrm{H}_{2} \mathrm{O}\right)$ stoichiometry was previously formed both for symmetric and asymmetric perfluorinated ligands: $R^{1}=R^{2}=C_{3}$ [19], $R^{1}=C_{3} F_{7}$, $\mathrm{R}^{2}=\mathrm{C}\left(\mathrm{CH}_{3}\right)_{3}$ [6]. However, anhydrous compounds were straightly obtained in some cases: $\mathrm{R}^{1}=\mathrm{CF}_{3}, \mathrm{R}^{2}=\mathrm{C}\left(\mathrm{CH}_{3}\right)_{3}[16] \mathrm{R}^{2}=\mathrm{C}\left(\mathrm{OCH}_{3}\right)\left(\mathrm{CH}_{3}\right)_{2}$ [17].

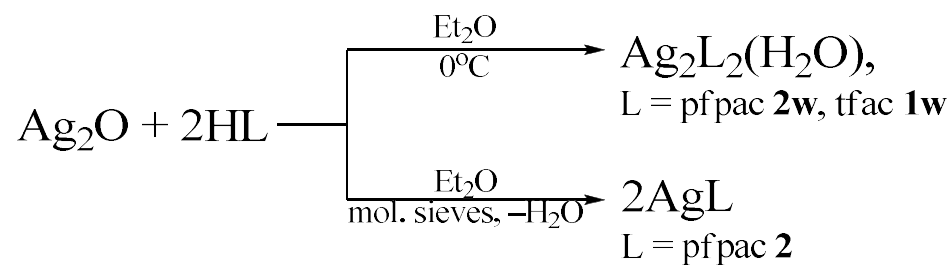

Scheme 2. The synthesis routes to obtain $\mathrm{Ag}(\mathrm{I})$ fluorinated $\beta$-diketonates.

In this work, we received aqua- $\beta$-diketonates $\mathbf{1 w}$ and $\mathbf{2 w}$. The tendency to form anhydrous crystals upon slow crystallization at low temperatures was previously noted for $[\mathrm{Ag}(\mathrm{tfac})]_{\infty} \mathbf{1}$ [15]. We confirmed this observation for both compounds, obtaining $\mathbf{1}$ and 2 crystals by another crystal growth method. Moreover, for the new pfpac-ligand, we have implemented an alternative strategy for the direct synthesis of the anhydrous coordination polymer 2 (Scheme 2). The idea was to capture the generated water, for which we used molecular sieves. The Schlenk technique was applied to prevent the capture of water from the environment. In this synthetic method, it was important that the product did not form as a precipitate, but was completely dissolved in the solvent used. This was easily achieved, due to observed significant increase in the solubility of the $\operatorname{Ag}(\mathrm{I}) \beta$-diketonate compound in ether with an increase in the fluorinated substituent length (evaluated up to $850 \mathrm{mg}$ 2w/100 $\mathrm{mL} \mathrm{Et}_{2} \mathrm{O}$ ).

The IR spectra of the obtained $\mathrm{Ag}(\mathrm{I}) \beta$-diketonates contain several characteristic series of bands. Stretching vibrations of C-H bonds $\left(3000-2800 \mathrm{~cm}^{-1}\right)$ appeared for all compounds, while vibrations of the $\mathrm{O}-\mathrm{H}$ bonds $\left(3500-3200 \mathrm{~cm}^{-1}\right)$ of water can be seen only in spectra of $\mathbf{1 w}$ and $\mathbf{2 w}$. This was confirmed by the recoding of spectra in fluorinated oil. The wavenumber region of $1650-1100 \mathrm{~cm}^{-1}$ contains several strong and medium peaks of following vibrations: stretching $\mathrm{C}=\mathrm{O}\left(\sim 1640,1553-1518, \sim 1465,1360 \mathrm{~cm}^{-1}\right)$, stretching $\mathrm{C}-\mathrm{F}\left(\sim 1190 \mathrm{~cm}^{-1}\right)$, and deformation $\mathrm{CF}_{3}\left(1130-1120 \mathrm{~cm}^{-1}\right)$. Frequencies of some weaker vibrations of $\mathrm{C}=\mathrm{C}$ and deformation $\mathrm{CH}_{3}$ are mostly superimposed with $\mathrm{C}=\mathrm{O}$ and $\mathrm{C}-\mathrm{F}$ peaks. It should be noted that peaks of stretching vibration of $\mathrm{C}-\mathrm{CF}_{3}$ bonds for pfpac-based compounds $\mathbf{2} \mathbf{w}$ and $\mathbf{2 a}$ are strongly shifted towards higher frequencies when compared to tfac-complexes 1, 1w, and 1a $\left(\sim 1330 \mathrm{~cm}^{-1}\right.$ versus $\left.\sim 1280 \mathrm{~cm}^{-1}\right)$, which can be associated with a change of substituent in thr $\beta$-diketonate ligand. Peaks in the range of $1030-900 \mathrm{~cm}^{-1}$ are associated with rotational $-\mathrm{CH}_{3}$ vibrations $\left(1030-1020 \mathrm{~cm}^{-1}\right.$, $\sim 990 \mathrm{~cm}^{-1}$ ) and stretching C-C vibrations $\left(935-920 \mathrm{~cm}^{-1}\right)$. It is interesting that the peak at 1030-1020 $\mathrm{cm}^{-1}$ is much more intensive for $\mathbf{2} \mathbf{w}$ and $\mathbf{2 a}$ than for $\mathbf{1}, \mathbf{1} \mathbf{w}$, and $\mathbf{1 a}$, which can also be associated with the influence of the terminal substituent in the ligand. The region of $850-500 \mathrm{~cm}^{-1}$ contains some medium and weak peaks of stretching and deformation C-C vibrations $\left(\sim 820 \mathrm{~cm}^{-1}\right), \pi$-system of $\beta$-diketonate vibrations $\left(810-800 \mathrm{~cm}^{-1}\right)$, and vibrations of chelate metallocycle $\left(\sim 760 \mathrm{~cm}^{-1}\right)$, as well as Ag-O $\left(\sim 760 \mathrm{~cm}^{-1}, 620-600 \mathrm{~cm}^{-1}\right)$ and Ag-C $\left(\sim 725 \mathrm{~cm}^{-1}, 570-550 \mathrm{~cm}^{-1}, 530-516 \mathrm{~cm}^{-1}\right)$. Some of these peaks are superimposed. Several typical IR spectra are given in Supplementary Materials (Figure S1). The set of bands in the IR spectra of compound 1 fully corresponds to that previously described in the work [15], which was used for detailed assignment. 
According to NMR data, there was no free $\beta$-diketonate ligand in the samples, which was confirmed by the absence of the $\mathrm{OH}$-group resonance in the ligands enol-form (resonance with chemical shift of more than $10 \mathrm{ppm}$ ). Coordination of the $\beta$-diketonate ligand to the silver leads to a slight shift of the $\mathrm{C}_{\alpha}-\mathrm{H}$ group resonance to the high-field region.

All the silver $\beta$-diketonates studied $(\mathbf{1}, \mathbf{2}, \mathbf{1 w}, \mathbf{2 w})$ are slowly soluble in water, but quickly soluble in polar O-donor solvents (alcohols, THF). However, the time-dependent stability of these solutions requires further study, since precipitation of silver or its oxide was observed upon exposure to light or heating. They also dissolved in N-donor $\left(\mathrm{CH}_{3} \mathrm{CN}\right)$ and aromatic (toluene) solvents, and the corresponding adducts $\mathrm{Ag}_{2}(\mathrm{~L})_{2}(\mathrm{Q})$ were formed upon evaporation. The stoichiometry of these products was confirmed by ${ }^{1} \mathrm{H}-\mathrm{NMR}$. This composition seems to be typical for the adducts of $\mathrm{Ag}(\mathrm{I}) \beta$-diketonates, since it was noted for various solvents and anionic ligands $[16,20,21]$. It was retained when the adduct crystals $\mathbf{1 t}, \mathbf{2} \mathbf{a}$, and $\mathbf{2 t}$ were grown from appropriate solvents. The exception was the acetonitrile adduct of $\mathrm{Ag}(\mathrm{tfac})$, whose crystals 1a correspond to one-equivalent stoichiometry.

It should be noted that the formation of the adducts with $\mathrm{CH}_{3} \mathrm{CN}$ were also demonstrated by IR through the appearance of a characteristic band at 2310 and $2280 \mathrm{~cm}^{-1}$, corresponding to $\mathrm{C} \equiv \mathrm{N}$ stretching vibrations (Figure $\mathrm{S} 1$, Supplementary Materials). At the same time, the bands of water vibrations disappeared. Both acetonitrile adducts $\mathrm{Ag}_{2}(\mathrm{~L})_{2}\left(\mathrm{CH}_{3} \mathrm{CN}\right)$ are storage stable, while the toluene adducts are rapidly converted to the corresponding aqua- $\beta$-diketonates $\mathbf{1 w}$ and $\mathbf{2 w}$. According to NMR, in the studied solutions, both toluene and acetonitrile most likely leave the metal coordination sphere, which is confirmed by the values of their chemical shifts, corresponding to free solvents in DMSO.

\subsection{Structural Features of $A g(I)$ Fluorinated $\beta$-Diketonates and Their Adducts}

According to single-crystal XRD data, the compounds under study $(\mathbf{1}, \mathbf{2}, \mathbf{1 a}, \mathbf{2 a}, \mathbf{1 t}, \mathbf{2 t})$ reveal chain-like structures of different spatial geometry that varies depending on the diketonate (tfac vs. pfpac) and the presence of toluene or acetonitrile ligands. The coordination number $(\mathrm{CN})$ of $\mathrm{Ag}$ atoms equals four in the case of non-solvent-containing compounds $\mathbf{1}$ and 2, while it equals five for the adducts. Similar to related Ag coordination polymers [17], the coordination polyhedron is highly distorted. For most of the central atoms of $\mathbf{1}$ and 2 , it can be best described as a vacant trigonal bipyramid $\left(C_{3 v}\right)$ according to the continuous shape measure analysis (Table S2, Supplementary Materials) [34]. For the $\mathrm{Ag}$ atoms of $\mathbf{1 a}, \mathbf{2 a}, \mathbf{1 t}$, and $\mathbf{2 t}$, the polyhedron is best described as a spherical square pyramid $\left(C_{4 v}\right)$ (Table S3, Supplementary Materials). Selected parameters of the silver coordination environment and chelate metallocycles are listed in Table 1 for the solvent-free coordination polymers $(\mathbf{1}, \mathbf{2})$ and in Table 2 for the adducts $(\mathbf{1 a}, \mathbf{2 a}, \mathbf{1 t}, \mathbf{2 t})$. The fragments of the structures are presented in Figures 1-3.

The $\beta$-diketonate ligands in compounds 1,2 , and 1 a have a $\mu_{3}-\kappa^{1}: k^{1}: k^{2}$ chelatebridging function via one $C$ and two $\mathrm{O}$ atoms. Compounds $1 \mathbf{t}, 2 \mathbf{t}$, and $2 \mathbf{a}$ comprise two types of the $\beta$-diketonates: one of them is the same as in the former cases, while another is $\mu_{2}-\kappa^{1}: \kappa^{2}$ chelate-bridging only via $\mathrm{O}$ atoms. The toluene ligands coordinate in $\eta^{2}$ manner; however, in $\mathbf{1 t}$, it binds via $C^{2}$ and $C^{3}$ atoms, while in $\mathbf{2 t}$ via $C^{3}$ and $C^{4}$ atoms. Such contacts at a relatively large distance (Table 2) lead to a low stability of these adducts (Par. 3.1). The difference in the coordination mode is likely caused by steric reasons. Note that the $\mathrm{Ag}-\mathrm{N}$ (acetonitrile) bond is noticeably shorter in $\mathbf{2 a}$ when compared to $\mathbf{1 a}$, which is probably also a consequence of steric effects and the presence of the stronger electron-withdrawing group $\left(\mathrm{C}_{2} \mathrm{~F}_{5}\right.$ vs. $\left.\mathrm{CF}_{3}\right)$.

The bond lengths Ag-O vary over a wide range of 2.26 (1)-2.732 (3) $\AA$, generally being shorter for the oxygens belonging to the chelate mode (Tables 1 and 2). In the adduct structure of one-equivalent stoichiometry 1a (Figure 3), the chain appears less tense, and is characterized by the largest minimum distances between the silver atoms (Table 2). The range of $\mathrm{Ag}-\mathrm{O}$ bond lengths here corresponds to solvent-free $\mathrm{Ag}$ (I) $\beta$-diketonates (Table 1). For the adducts of half-stoichiometry $\mathbf{1 t}, \mathbf{2 t}$, and $\mathbf{2 a}$, there are elongated $\mathrm{Ag}-\mathrm{O}$ distances exhibited by the Ag atom that connected with a solvent molecule (Table 2). In the case of 
toluene adducts $\mathbf{1 t}$ and $\mathbf{2 t}$, these distances are realized with $\mu_{3}-\mathrm{O}$ of $\beta$-diketonate-ligand $(\sim 2.72 \AA)$, while for the acetonitrile adduct $2 \mathrm{a}$ the distance is noticeably shorter $(\sim 2.60 \AA)$ and realized with $\mu_{2}-\mathrm{O}$.

Table 1. Selected distances and angles in the structures $[\mathrm{Ag}(\mathrm{tfac})]_{\infty} \mathbf{1}$ and $[\mathrm{Ag}(\mathrm{pfpac})]_{\infty} \mathbf{2}$.

\begin{tabular}{|c|c|c|}
\hline Coordination Polymer & {$[\mathrm{Ag}(\mathrm{tfac})]_{\infty}$} & {$[A g(p f p a c)]_{\infty}$} \\
\hline Identification code & 1 & 2 \\
\hline \multicolumn{3}{|c|}{ Distance, $\AA$} \\
\hline $\mathrm{Ag}-\mathrm{O}_{\beta \text {-dik }}$ (chelate, non-bridging) & $2.328(6), 2.374(6)$ & $2.37(1)-2.46(2)$ \\
\hline $\mathrm{Ag}-\mathrm{O}_{\beta}$-dik (chelate, bridging) & $2.374(6)$ & $2.37(1)-2.43(1)$ \\
\hline $\mathrm{Ag}-\mathrm{O}_{\beta \text {-dik }}$ (non-chelate, bridging) & $2.466(6)$ & $2.26(1)-2.37(1)$ \\
\hline $\mathrm{Ag}-\mathrm{C}_{\alpha}$ & $2.336(8)$ & $2.25(2)-2.32(2)$ \\
\hline $\mathrm{Ag} \cdots \mathrm{Ag}$ (min., in the chain) & $3.666(2)$ & $3.43(1)-4.25(1)$ \\
\hline $\mathrm{Ag} \cdots \mathrm{Ag}$ (min., between the chains) & $2.861(2)$ & $7.80(1)$ \\
\hline \multicolumn{3}{|c|}{ Angle, ${ }^{\circ}$} \\
\hline $\mathrm{O}-\mathrm{Ag}-\mathrm{O}_{\beta \text {-dik }}$ (chelate) & $77.0(3)$ & $71.9(5)-76.2(5)$ \\
\hline \multicolumn{3}{|c|}{ Deformation of chelate metallocycle $\mathrm{AgO}_{2} \mathrm{C}_{3}$ : angle between the planes, ${ }^{\circ}$} \\
\hline$\left(\mathrm{Ag}, \mathrm{O}, \mathrm{O}_{\beta}\right) \&\left(\mathrm{O}, \mathrm{C}, \mathrm{C}_{\beta}, \mathrm{O}_{\beta}\right)$ & 162.2 & $156.4-159.8$ \\
\hline$\left(\mathrm{C}, \mathrm{C}_{\alpha}, \mathrm{C}_{\beta}\right) \&\left(\mathrm{O}, \mathrm{C}, \mathrm{C}_{\beta}, \mathrm{O}_{\beta}\right)$ & 170.1 & $168.5-172.2$ \\
\hline
\end{tabular}

Table 2. Selected distances and angles in the structures of the adducts $\mathbf{1 a}, \mathbf{2 a}, \mathbf{1 t}$, and $\mathbf{2 t}$. Elongated $\mathrm{Ag}-\mathrm{O}$ bonds are underlined. If noted, the additional designation of silver atoms means: $\mathrm{Ag}(\mathrm{NS})=$ non-solvent-connected $\mathrm{Ag}$ atom, $\operatorname{Ag}(\mathrm{S})=$ solvent-connected $\mathrm{Ag}$ atom

\begin{tabular}{|c|c|c|c|c|}
\hline \multirow{3}{*}{$\begin{array}{c}\text { General Formula } \\
\text { L } \\
\text { Q }\end{array}$} & \multicolumn{4}{|c|}{$\left[\operatorname{Ag}_{2}(L)_{2}(Q)\right]_{\infty}$} \\
\hline & \multicolumn{2}{|c|}{ tfac } & \multicolumn{2}{|c|}{ pfpac } \\
\hline & $\mathrm{CH}_{3} \mathrm{CN}, \mathrm{X}=\mathrm{N}$ & $\mathrm{C}_{7} \mathrm{H}_{8}, \mathrm{X}=\mathrm{C}$ & $\mathrm{CH}_{3} \mathrm{CN}, \mathrm{X}=\mathrm{N}$ & $\mathrm{C}_{7} \mathrm{H}_{8}, \mathrm{X}=\mathrm{C}$ \\
\hline Identification Code & $1 \mathbf{a}$ & $1 t$ & $2 \mathbf{a}$ & $2 t$ \\
\hline \multicolumn{5}{|c|}{ Distance, $\AA$} \\
\hline $\operatorname{Ag}(S)-X$ & - & $2.650(2), 2.548(2)$ & $2.180(3)$ & $2.481(5)$ \\
\hline $\mathrm{Ag}$ (NS)- $\mathrm{O}_{\beta \text {-dik }}$ (chelate, non-bridging) & - & $2.344(2)$ & $2.370(2)$ & $2.346(3)$ \\
\hline $\mathrm{Ag}(\mathrm{S})-\mathrm{O}_{\beta \text {-dik }}$ (chelate, non-bridging) & $2.395(2)$ & - & - & - \\
\hline Ag (NS)- $\mathrm{O}_{\beta \text {-dik }}$ (chelate, bridging) & - & $2.412(2)-2.455(2)$ & $2.358(2)-2.472(2)$ & $2.365(3)-2.515(4)$ \\
\hline $\mathrm{Ag}(\mathrm{S})-\mathrm{O}_{\beta}$-dik (chelate, bridging) & $2.439(2)$ & $2.388(2), 2.714(2)$ & $2.474(2), 2.596(2)$ & $2.484(4), 2.732(3)$ \\
\hline $\mathrm{Ag}(\mathrm{S})-\mathrm{O}_{\beta \text {-dik }}$ (non-chelate, bridging) & $2.459(2)$ & $2.397(2), \overline{2.404(2)}$ & $2.326(2), \overline{2.488(2)}$ & $2.292(3), 2.432(4)$ \\
\hline $\mathrm{Ag}(\mathrm{NS})-\mathrm{C}_{\alpha}$ & - & $2.369(2)$ & $2.390(3)$ & $2.487(5)$ \\
\hline $\mathrm{Ag}(\mathrm{S})-\mathrm{C}_{\alpha}$ & $2.468(2)$ & - & - & - \\
\hline $\mathrm{Ag} \cdots \mathrm{Ag}$ (min., in the chain) & $3.820(2)$ & $3.1235(4)$ & $3.2379(3)$ & $3.1087(6)$ \\
\hline \multicolumn{5}{|c|}{ Angle, ${ }^{\circ}$} \\
\hline $\mathrm{O}-\mathrm{Ag}-\mathrm{O}_{\beta \text {-dik }}($ chelate $)$ & $75.40(6)$ & $67.53(5)-76.67(6)$ & $66.79(7)-75.82(8)$ & $69.7(1)-77.1(1)$ \\
\hline Ag $\cdots A g \cdots A g$ (in the chain) & $71.9,108.1$ & $69.8,110.2$ & $64.0,116.0$ & $72.4,107.6$ \\
\hline \multicolumn{5}{|c|}{ Deformation of chelate metallocycle $\mathrm{AgO}_{2} \mathrm{C}_{3}$ : angle between the planes, ${ }^{\circ}$} \\
\hline$\left(\mathrm{Ag}, \mathrm{O}, \mathrm{O}_{\beta}\right) \&\left(\mathrm{O}, \mathrm{C}, \mathrm{C}_{\beta}, \mathrm{O}_{\beta}\right)$ & 160.8 & $130.3-147.3$ & $132.0,148.4$ & $123.4-153.4$ \\
\hline$\left(\mathrm{C}, \mathrm{C}_{\alpha}, \mathrm{C}_{\beta}\right) \&\left(\mathrm{O}, \mathrm{C}, \mathrm{C}_{\beta}, \mathrm{O}_{\beta}\right)$ & 173.2 & $169.4,178.3$ & $172.6,179.0$ & $175.4,176.3$ \\
\hline
\end{tabular}

It should be noted that the structures of 2 and all the adducts belong to the chain polymeric motif. In compound 1, each chain is connected via short contacts Ag $\cdots A g$ of $2.82 \AA$ with the neighboring ones, spreading in the perpendicular direction (Figure 1). As a result, compound $\mathbf{1}$ features a 3D coordination framework. 

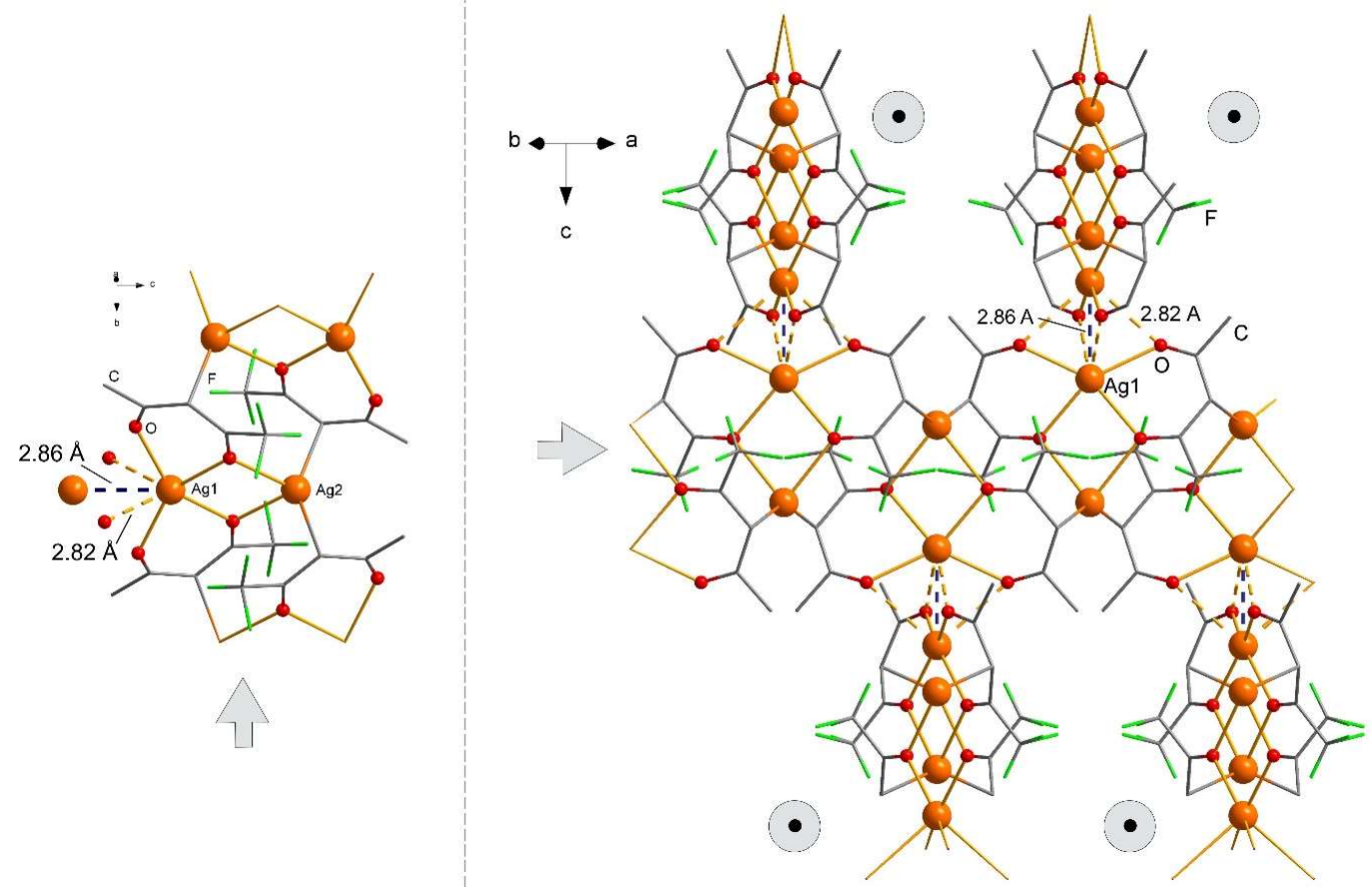

Figure 1. Fragments of the structure of compound $[\mathrm{Ag}(\mathrm{tfac})]_{\infty} \mathbf{1}$ in two projections. $\mathrm{C}$ and $\mathrm{F}$ atoms are shown in a sticks model, $\mathrm{H}$ atoms are omitted. Dashed lines indicate $\mathrm{Ag} \cdots \mathrm{O}$ and $\mathrm{Ag} \cdots \mathrm{Ag}$ contacts longer than $2.60 \AA$. Centered circles indicate perpendicular to the figure direction of chain propagation, arrows indicate a vertical or horizontal direction. Disorder of the $\mathrm{CF}_{3}$ group is not shown. Atoms' coloring scheme: orange- $\mathrm{Ag}$, red- $\mathrm{O}$, gray $-\mathrm{C}$, green $-\mathrm{F}$.

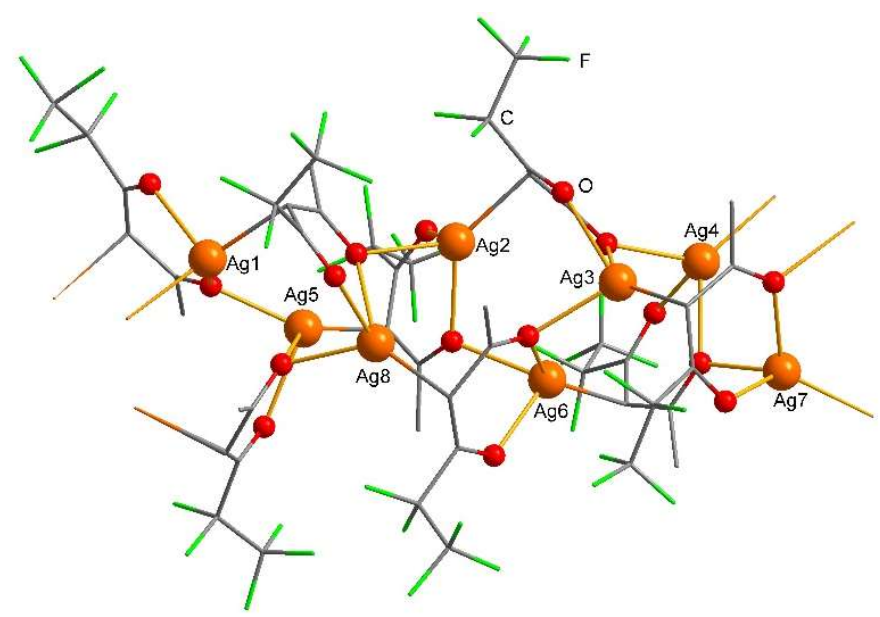

Figure 2. A fragment of the structure of compound $[\mathrm{Ag} \text { (pfpac) }]_{\infty} 2$. C and $\mathrm{F}$ atoms are shown in a sticks model, $\mathrm{H}$ atoms are omitted. Atoms' coloring scheme: orange $-\mathrm{Ag}$, red $-\mathrm{O}$, gray $-\mathrm{C}$, green $-\mathrm{F}$.

To construe the observed structural diversity, we analyzed in the same manner the structures presented in this work and the earlier published toluene and acetonitrile adducts:

$1 \quad\left[\mathrm{Ag}_{2}(\mathrm{hfac})_{2}\left(\mathrm{C}_{7} \mathrm{H}_{8}\right)\right] 3 \mathbf{t}[20]$ (hfac =1,1,1,5,5,5-hexafluoro-3,5-pentanedionate, $\left.\mathrm{R}^{1}=\mathrm{R}^{2}=\mathrm{CF}_{3}\right)$;

$2\left[\mathrm{Ag}_{2}(\mathrm{btfac})_{2}\left(\mathrm{CH}_{3} \mathrm{CN}\right)\right]$ 4a [21] (btfac = 4,4,4-trifluoro-1-phenyl-1,3-butanedionate, $\left.\mathrm{R}^{1}=\mathrm{CF}_{3}, \mathrm{R}^{2}=\mathrm{C}_{6} \mathrm{H}_{5}\right)$;

$\left.3 \mathrm{Ag}_{2}(\mathrm{nphtfac})_{2}\left(\mathrm{CH}_{3} \mathrm{CN}\right)\right] 5 \mathbf{5}$ [21] (nphtfac = 4,4,4-trifluoro-1-(2-naphthyl)-1,3-butanedione, $\left.\mathrm{R}^{1}=\mathrm{CF}_{3}, \mathrm{R}^{2}=\mathrm{C}_{10} \mathrm{H}_{7}\right)$. 


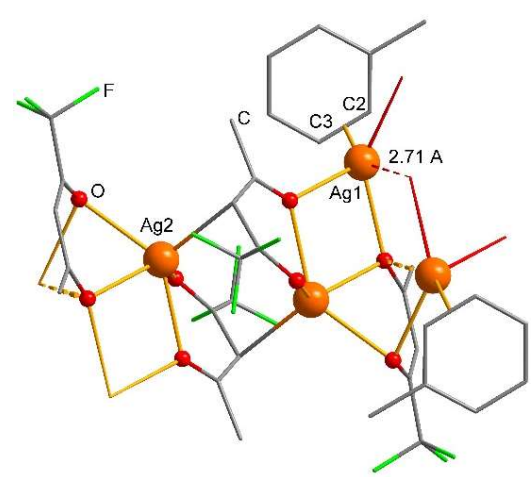

$1 t$

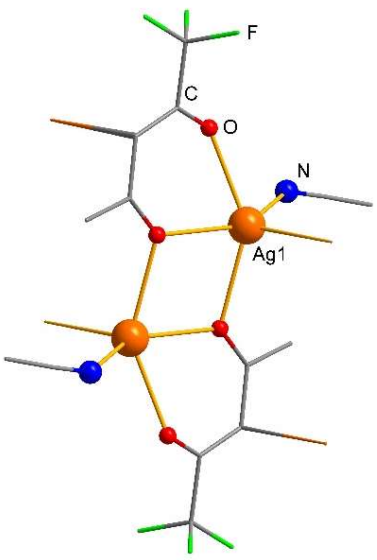

$1 \mathbf{a}$

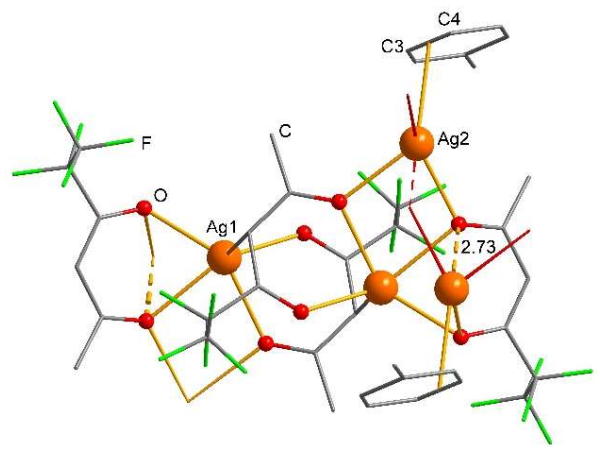

$2 t$

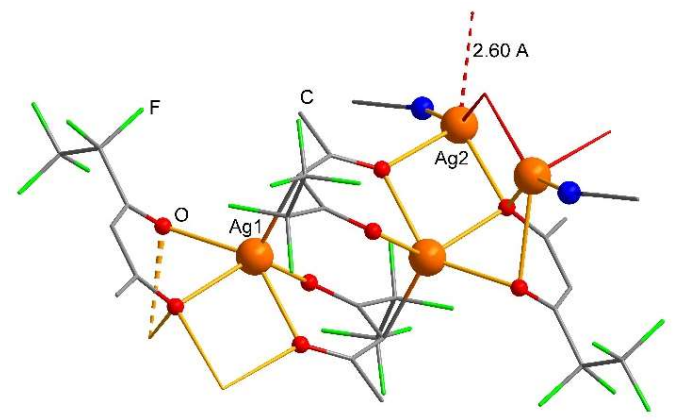

2a

Figure 3. A fragment of the structure of the compounds $1 \mathbf{t}, \mathbf{2 t}, \mathbf{1} \mathbf{a}$ and $\mathbf{2 a}$. $\mathrm{C}$ and $\mathrm{F}$ atoms are shown in a sticks model, $\mathrm{H}$ atoms are omitted. Dashed lines indicate Ag... O contacts longer than $2.60 \AA$. Atoms' coloring scheme: orange $-\mathrm{Ag}$, red $-\mathrm{O}$, gray $-\mathrm{C}$, green $-\mathrm{F}$, blue $-\mathrm{N}$.

We distinguished several types of secondary building units (SBUs) in these structures.

The first SBU type is the $\left\{\mathrm{Ag}(\beta \text {-dik })_{2}\right\}$ block with two chelating anions. This type was revealed in the structures $\mathbf{1}$, two semi-equivalent toluene adducts (1t and $\mathbf{2 t}$ ), and all the semi-equivalent acetonitrile adducts $(\mathbf{2} \mathbf{a}, \mathbf{4 a}, \mathbf{5 a})$, and is connected in chains via $\mathrm{Ag}$ atoms (Figure 4). In the structure of solvent-free coordination polymers, $[\mathrm{Ag}(\mathrm{tfac})]_{\infty} \mathbf{1}$, the $\left\{\mathrm{Ag}(\beta \text {-dik })_{2}\right\}$ SBUs are separated from each other and alternate with Ag atoms coordinating two $\mathrm{O}$ and two $\mathrm{C}$ atoms (Figure 4a). In all the solvent-containing structures, the $\left\{\mathrm{Ag}(\beta-\mathrm{dik})_{2}\right\}$ SBUs are pairwise connected via $\mathrm{Ag}-\mathrm{C} \alpha$ bonds. However, $\mathrm{Ag}$ in $\{\mathrm{Ag}$ (solvent) $\}$ SBUs coordinates either four $\mathrm{O}$ atoms (two oxygens from one ligand of the first $\left\{\mathrm{Ag}(\beta \text {-dik })_{2}\right\}$ and two oxygens from two ligands of the second $\left.\left\{\mathrm{Ag}(\beta \text {-dik })_{2}\right\}\right)$ in the case of $\mathbf{2 a}, \mathbf{1 t}, \mathbf{2 t}$ (Figure $4 \mathbf{b}$ ), or two $\mathrm{O}$ and one $\mathrm{C}$ atom in the case of $\mathbf{4 a}$ and $\mathbf{5 a}$ (Figure $4 \mathrm{c}$ ). The different motifs of the chains for the adducts likely arise from different substituents in the $\beta$-diketonate backbone: the latter two structures comprise bulky aryl groups, while our structures comprise small $\mathrm{CH}_{3}$ groups.

The second SBU type is the $\{\mathrm{Ag}(\beta$-dik $)\}$ block with one chelating anion that connects with each other in chains via $\mathrm{Ag}-\mathrm{C}_{\alpha}$ bonds (Figure 5). These SBUs are presented in [Ag (pfpac) $]_{\infty} 2$ and $\left[\mathrm{Ag}(\mathrm{tfac})\left(\mathrm{CH}_{3} \mathrm{CN}\right)\right] \mathbf{1 a}$. In both structures, each chain connects with the neighboring one via $\mathrm{Ag}-\mathrm{O}$ bonds; however, in the adduct 1a, the two bonds are formed within the pair of $\{\mathrm{Ag}(\beta$-dik) $\}$ SBUs (Figure $5 \mathrm{a})$, while in solvent-free coordination polymer 2, each $\{\mathrm{Ag}$ ( $\beta$-dik)\} forms Ag-O bonds with two different SBUs (Figure $5 b$ ). Interestingly, the latter structure manifests itself as a double stranded one, akin to a DNA strand (Figure 6). 


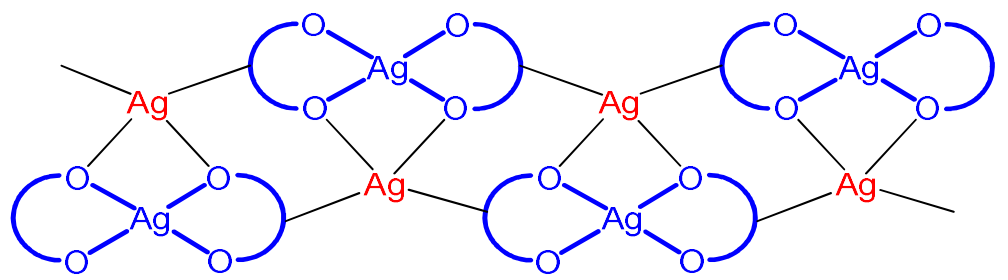

(a)

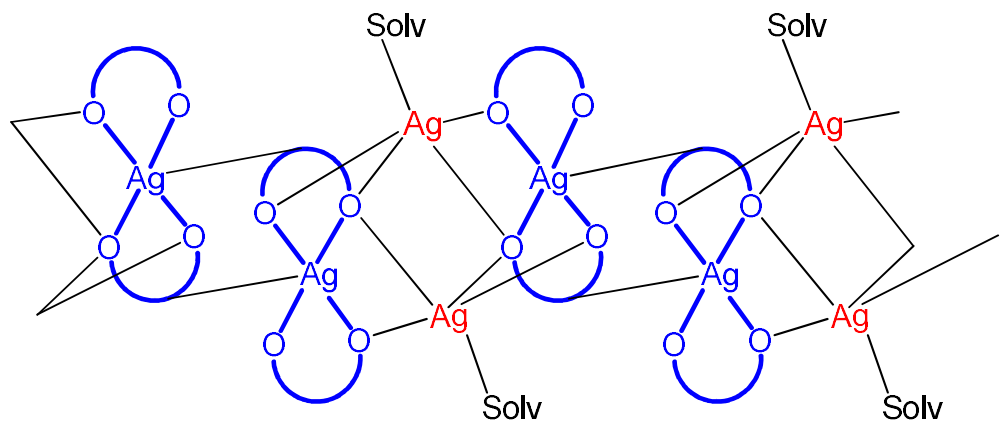

(b)

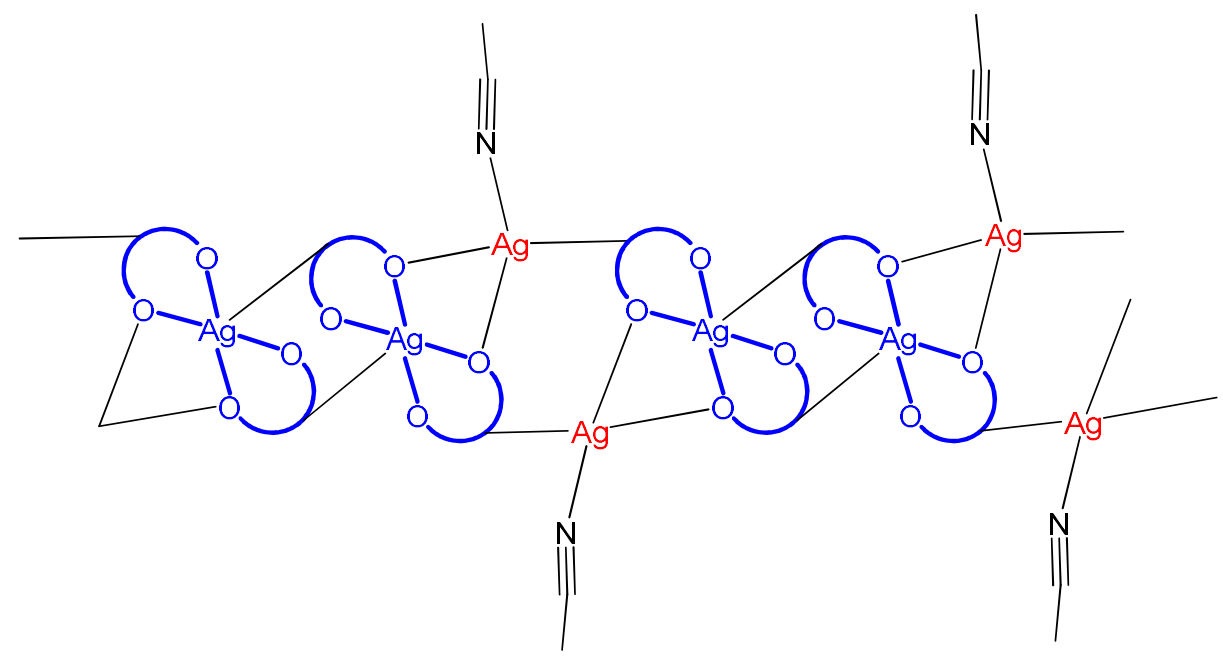

(c)

Figure 4. Schematic representation of (a) $[\mathrm{Ag}(\mathrm{tfac})]_{\infty} \mathbf{1}$; (b) $\left[\mathrm{Ag}_{2}(\mathrm{pfpac})_{2}\left(\mathrm{CH}_{3} \mathrm{CN}\right)\right]$ 2a and $\left[\mathrm{Ag}_{2}(\mathrm{~L})_{2}\left(\mathrm{C}_{7} \mathrm{H}_{8}\right)\right]\left(\mathrm{L}=\right.$ tfac 1t, pfpac 2t); (c) $\left[\mathrm{Ag}_{2}(\mathrm{~L})_{2}\left(\mathrm{CH}_{3} \mathrm{CN}\right)\right](\mathrm{L}=$ btfac 4a, nphtfac 5a). The substituents in $\beta$-ligands are omitted for clarity. $\left\{\mathrm{Ag}(\beta \text {-dik })_{2}\right\}$ SBUs are marked blue.

Finally, it is interesting to note that, despite the same stoichiometry, the structure of the toluene adduct $\mathbf{4 t}$ with the hfac-ligand is fundamentally different from the adducts $\mathbf{1 t}$ and $\mathbf{2 t}$ obtained in this work. The coordination polymer $\mathbf{4 t}$ exhibits not a chain, but a layered motif, where the $\{\mathrm{Ag}(\beta$-dik) $\}$ SBUs are connected via Ag-O bonds into tetranuclear fragments, which are further connected by bridging toluene ligands (Figure 7). In contrast to the compounds discussed above, the structure $4 \mathbf{t}$ features no Ag-C $\alpha$ bonds with the $\beta$-diketonate.

\subsection{Thermal Analysis}

Thermal properties of the compounds were studied in an inter-atmosphere (helium flow). For a new family of Ag (I) pfpac-compounds we compared the behavior of pristine $\beta$-diketonate $\mathbf{2}$ with its water $\mathbf{2 w}$ and acetonitrile $\mathbf{2 a}$ adducts (Figure 8a). 


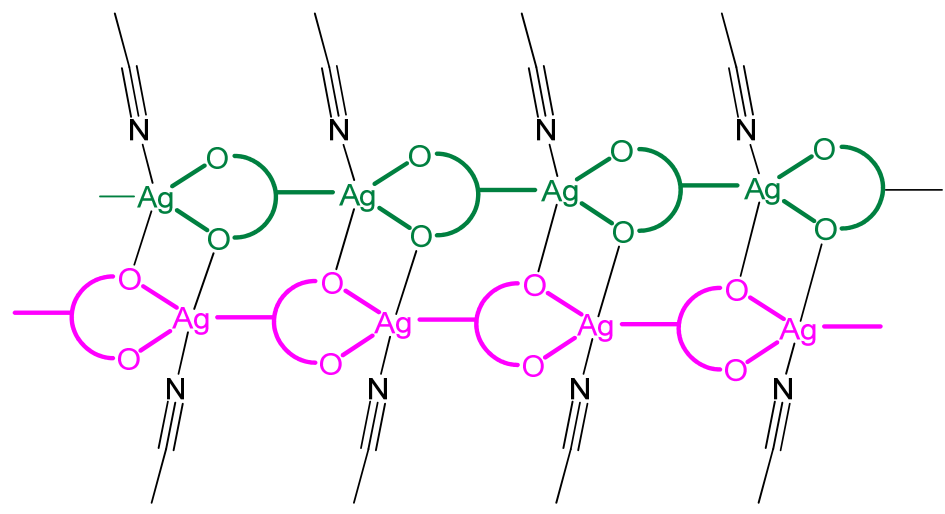

(a)

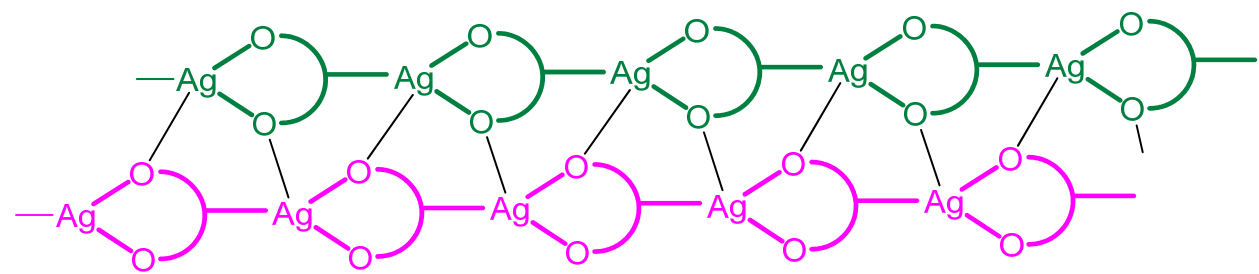

(b)

Figure 5. Schematic representation of (a) $\left[\mathrm{Ag}(\mathrm{tfac})\left(\mathrm{CH}_{3} \mathrm{CN}\right)\right] \mathbf{1 a} ;(\mathbf{b})[\mathrm{Ag}(\mathrm{pfpac})]_{\infty} \mathbf{2}$. The substituents in $\beta$-ligands are omitted for clarity. $\{\mathrm{Ag}(\beta$-dik $)\}$ SBUs are marked green and pink.

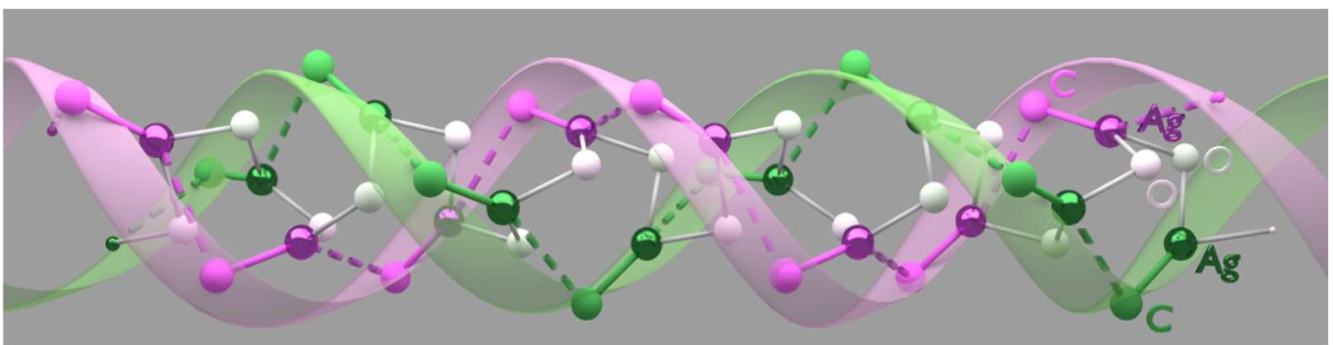

Figure 6. Schematic representation of $[\mathrm{Ag}(\mathrm{pfpac})]_{\infty} 2$ stranded structure. Only Ag and bridging $\mathrm{O}$ and $\mathrm{C}$ atoms are shown. The positions of the ligands are depicted as dashed lines, translucent ribbons show the twist of the chains.

The mass loss of the adducts starts from the solvent elimination: for $\mathbf{2 w}$ : calcd. $\omega\left(\frac{1}{2} \mathrm{H}_{2} \mathrm{O}\right)=2.9 \%$, exp. the first mass loss step $=2.6 \%$; for $2 \mathrm{a}$ : calcd. $\omega\left(\frac{1}{2} \mathrm{CH}_{3} \mathrm{CN}\right)=6.2 \%$, exp. the first mass loss step $=6.6 \%$. It should be noted that water is lost at $30-60{ }^{\circ} \mathrm{C}$, while acetonitrile is lost at higher temperatures $\left(50-90^{\circ} \mathrm{C}\right)$. This may indicate a weaker binding of water molecules. Moreover, according to differential TG curves (DTG), water eliminates at one step, while $\mathrm{CH}_{3} \mathrm{CN}$ leaves the coordination sphere in two steps (Figure 8a). According to c-DTA, solvent removal is endothermic.

The solvent-free coordination polymer 2 is stable up to roughly $115^{\circ} \mathrm{C}$ (for all samples), and the major mass loss proceeds in one step and is completed before $200{ }^{\circ} \mathrm{C}$. Then, a slow small mass loss occurs, which can be attributed to the annealing of the carbon products of the compounds' decomposition. XRPD shows a single crystalline decomposition product, namely, metallic silver (PDF 010-89 3722 [35]). However, the calculations of the mass loss curves allow the suggesting of the presence of an amorphous component: for $\mathbf{2 w}$ calcd. $\omega(\mathrm{Ag})=33.7 \%$, exp. $\omega$ (residue $)=36.4 \%$; for 2 a calcd. $\omega(\mathrm{Ag})=32.5 \%$, exp. $\omega$ (residue $)=36.0 \%$; for 2 calc. $\omega(\mathrm{Ag})=34.7 \%$, exp. $\omega$ (residue $)=37.5 \%$ ). This component is likely an unannealed amorphous carbon. 


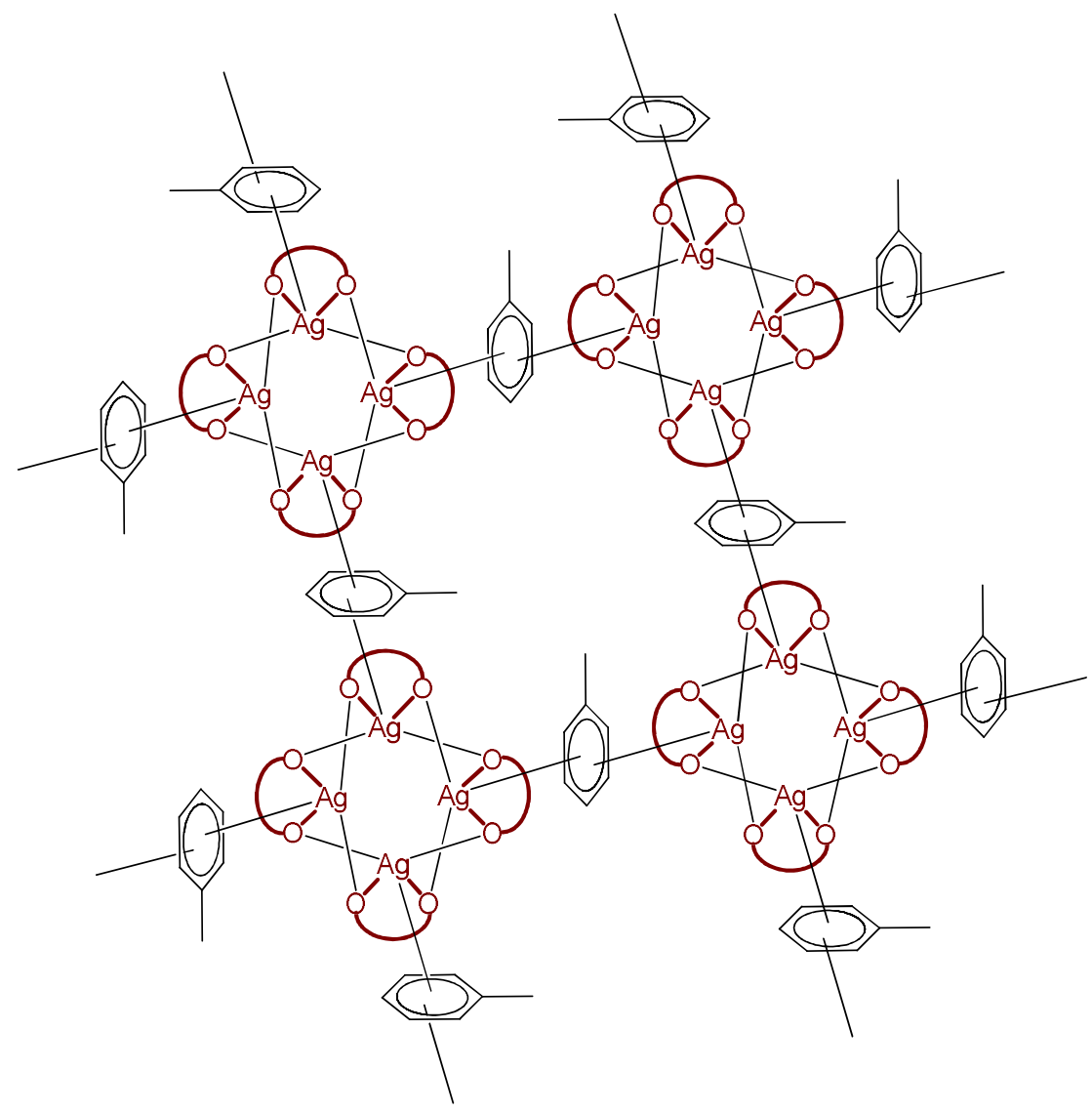

Figure 7. Schematic representation of $\left[\mathrm{Ag}_{2}(\mathrm{hfac})_{2}\left(\mathrm{C}_{7} \mathrm{H}_{8}\right)\right]$ 3t. $\{\mathrm{Ag}(\beta-$ dik $)\}$ SBUs are marked wine.

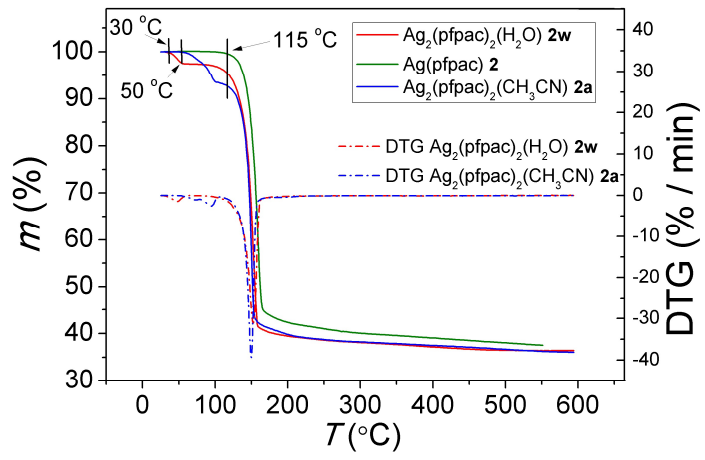

(a)

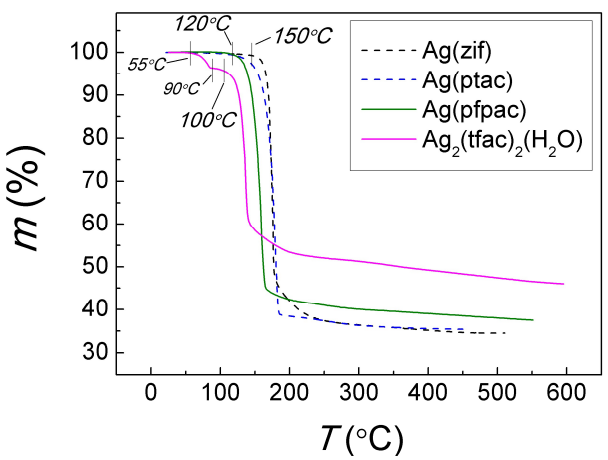

(b)

Figure 8. Thermal analysis data for (a) $[\mathrm{Ag}(\mathrm{pfpac})]_{\infty} \mathbf{2}$ and its water $\mathbf{2} \mathbf{w}$ and acetonitrile $\mathbf{2 a}$ adducts (b) a row of $\mathrm{Ag}$ (I) compounds with fluorinated $\beta$-diketonates $\mathrm{R}^{1} \mathrm{C}(\mathrm{O}) \mathrm{C}_{\alpha} \mathrm{HC}(\mathrm{O}) \mathrm{R}^{2}: \mathrm{R}^{1}=\mathrm{C}_{2} \mathrm{~F}_{5}$, $\mathrm{R}^{2}=\mathrm{CH}_{3}$ (pfpac), $\mathrm{R}^{1}=\mathrm{CF}_{3}, \mathrm{R}^{2}=\mathrm{CH}_{3}$ (tfac), $\mathrm{C}\left(\mathrm{CH}_{3}\right)_{3}$ (ptac), $\mathrm{C}\left(\mathrm{OCH}_{3}\right)\left(\mathrm{CH}_{3}\right)_{2}$ (zif).

Within a family of tfac-based compounds, aqua- $\beta$-diketonate $1 \mathbf{w}$ was studied (Figure $8 \mathrm{~b}$ ). Similar to $\mathbf{2 w}$, the first mass loss step corresponds to endothermic water elimination: calcd. $\omega\left(\frac{1}{2} \mathrm{H}_{2} \mathrm{O}\right)=3.3 \%$, exp. mass loss value $\left.=3.7 \%\right)$. However, this process occurs at higher temperatures $\left(55-90^{\circ} \mathrm{C}\right)$. Apparently, in adduct $\mathbf{1 w}$, water is connected by stronger interactions than in $\mathbf{2 w}$, despite the presence of a stronger electroacceptor substituent in $2 \mathbf{w}\left(\mathrm{C}_{2} \mathrm{~F}_{5}\right.$ versus $\mathrm{CF}_{3}$ ). This may indicate completely different structures of the considered aqueous adducts. The decomposition of solvent-free coordination polymer $\mathbf{1}$ starts at $100{ }^{\circ} \mathrm{C}$.

The thermal behavior of the Ag (I) $\beta$-diketonates considered here was compared with the data obtained under similar conditions for the related solvent-free fluorinated $\left[\mathrm{Ag}\left(\mathrm{R}^{1} \mathrm{C}(\mathrm{O}) \mathrm{C}_{\alpha} \mathrm{HC}(\mathrm{O}) \mathrm{R}^{2}\right]_{\infty}\right.$ compounds containing a bulky non-fluorinated substituent: 
$\mathrm{R}^{1}=\mathrm{CF}_{3}, \mathrm{R}^{2}=\mathrm{C}\left(\mathrm{CH}_{3}\right)_{3}$ (ptac), $\mathrm{C}\left(\mathrm{OCH}_{3}\right)\left(\mathrm{CH}_{3}\right)_{2}$ (zif) (Figure 8b). All these complexes were decomposed to metallic silver (XRPD). Herewith, $\mathrm{Ag}$ (tfac) 1, which alone contains argentophilic interactions in the structure, is the least terminally stable, while Ag (zis) where the silver coordination is supplemented by an $\mathrm{Ag}-\mathrm{O}_{\mathrm{CH} 3}$ bond, is the most stable. The other two $\beta$-diketonates are comparable in thermal stability.

\section{Conclusions}

Silver (I) $\beta$-diketonate complexes exhibit great potential for structural design and the formation of various building blocks, both due to the various modes of ligand coordination (by oxygen atoms and/or methine carbon) and via the inclusion of solvents. Herein, we have investigated the effect of a fluorinated substituent $\left(\mathrm{CF}_{3} / \mathrm{C}_{2} \mathrm{~F}_{5}\right)$ and $\mathrm{N}$-donor $\left(\mathrm{CH}_{3} \mathrm{CN}\right)$ and aromatic (toluene) solvents on the structural and thermal properties of this class of the silver compounds. The results obtained were analyzed in comparison with a series of related, fluorinated Ag (I) $\beta$-diketonates and their acetonitrile and toluene adducts. Thus, we have identified characteristic secondary building units and several new types of structural organization of these coordination polymers.

In particular, for fluorinated Ag (I) $\beta$-diketonates, the coordination polymer with a small-size methyl substituent (tfac) possesses a 3D framework structure based on argentophilic interactions, and therefore is the least thermally stable. An increase of bulkiness in both fluorinated $\left(\mathrm{CF}_{3} \rightarrow \mathrm{C}_{2} \mathrm{~F}_{5}\right)$ and non-fluorinated $\left(\mathrm{CH}_{3} \rightarrow \mathrm{C}\left(\mathrm{CH}_{3}\right)_{3} / \mathrm{C}\left(\mathrm{OCH}_{3}\right)\right.$ $\left.\left(\mathrm{CH}_{3}\right)_{2} / \mathrm{C}_{6} \mathrm{H}_{5}\right)$ substituents leads to the expected decrease in the structural dimension to $2 \mathrm{D}$ (double chains). The mutual repulsion of large-size fluorinated substituents $\left(\mathrm{C}_{2} \mathrm{~F}_{5}\right)$ leads to structural reorganization and helical twisting of two chains.

For Ag (I) $\beta$-diketonate adducts, the stoichiometry is not the main structure-determining parameter. In fact, three motifs of structural organization were found for $\left[\mathrm{Ag}_{2}(\mathrm{~L})_{2}(\mathrm{Q})\right]_{\infty}$ polymers $\left(\mathrm{Q}=\mathrm{CH}_{3} \mathrm{CN}\right.$, toluene). At the same time, these adducts with different $\beta$-diketonate-ligand and solvents can form the same structure motif. This includes the chain structures of both $\mathrm{CH}_{3} \mathrm{CN}$ and toluene adducts with asymmetric fluorinated $\beta$-diketonates $\left(\mathrm{R}^{1}=\mathrm{CH}_{3}\right.$, $\left.\mathrm{R}^{2}=\mathrm{CF}_{3} / \mathrm{C}_{2} \mathrm{~F}_{5}\right)$. The introduction of an aromatic non-fluorinated substituent into the anion leaves the main structure motif $(1 \mathrm{D}$, double chains), changing the chain organization. However, the latter was shown only for acetonitrile adducts. Finally, the presence of two $\mathrm{CF}_{3}$-groups in the $\beta$-diketonate-anion allows for the bridging function of toluene in the adduct structure. Thus, the combination of solvent and $\beta$-diketonate is important here, but more structural data is needed to understand the general trends. However, the adducts with acetonitrile are evidently more stable when compared to that with toluene owing due to better binding.

The obtained compounds broaden a family of silver (I) coordination polymers and might be employed to obtain Ag-containing functional materials. The exploration of their biological properties can also be a subject of further research.

Supplementary Materials: The following supporting information can be downloaded at. Figure S1: Typical IR spectra of the samples; Table S1: Crystal data and structure refinement for the compounds; Table S2: Geometry analysis of the complexes showing coordination number of Ag of 4 by SHAPE software; Table S3: Geometry analysis of the complexes showing coordination number of Ag of 5 by SHAPE software.

Author Contributions: Conceptualization, E.S.V.; Investigation, E.S.V., T.S.S., I.Y.I. and S.A.G.; Writing-Original Draft Preparation, E.S.V., T.S.S., I.Y.I. and S.A.G.; Writing-Review \& Editing, N.B.M.; Visualization, T.S.S. and S.A.G.; Supervision, N.B.M.; Project Administration, E.S.V. All authors have read and agreed to the published version of the manuscript.

Funding: This research was carried out with the support of the grant of the President of the Russian Federation for young scientists-candidates of sciences MK-6148.2021.1.3. The research was also supported by the Ministry of Science and Higher Education of the Russian Federation, N 121031700314-5 and 121031700313-8.

Institutional Review Board Statement: Not applicable. 
Informed Consent Statement: Not applicable.

Data Availability Statement: The data presented in this study are available on request from the corresponding author. The CIF files containing full crystallographic data for $\mathbf{1}, \mathbf{2}, \mathbf{1 a}, \mathbf{2 a}, \mathbf{1 t}, \mathbf{2 t}$ (CCDC 2131021-2131026) can be obtained free of charge via http:/ / www.ccdc.cam.ac.uk/conts/retrieving. html (accessed on 27 December 2021) (or from the CCDC, 12 Union Road, Cambridge CB2 1EZ, UK; Fax: +44-1223-336033; E-mail: deposit@ccdc.cam.ac.uk).

Acknowledgments: Authors would like to acknowledge the Multi-Access Chemical Research Center SB RAS for analytical measurements (C, H, F analysis). The authors also thank XRD Facility of NIIC SB RAS for the data collection.

Conflicts of Interest: The authors declare no conflict of interest.

Sample Availability: Samples of the compounds 1, 2, 1a, 2a, 1t, and $\mathbf{2 t}$ are available from the authors.

\section{References}

1. Condorelli, G.G.; Malandrino, G.; Fragalà, I.L. Engineering of molecular architectures of $\beta$-diketonate precursors toward new advanced materials. Coord. Chem. Rev. 2007, 251, 1931-1950. [CrossRef]

2. Vigato, P.A.; Peruzzo, V.; Tamburini, S. The evolution of $\beta$-diketone or $\beta$-diketophenol ligands and related complexes. Coord. Chem. Rev. 2009, 253, 1099-1201. [CrossRef]

3. Mishra, S.; Daniele, S. Metal-organic derivatives with fluorinated ligands as precursors for inorganic nanomaterials. Chem. Rev. 2015, 115, 8379-8448. [CrossRef]

4. Kremer, M.; Englert, U.N. Donor substituted acetylacetones-Versatile ditopic ligands. Z. Kristallogr. Cryst. Mater. 2018, 233, 437-452. [CrossRef]

5. Blake, A.J.; Champness, N.R.; Howdle, S.M.; Webb, P.B. Silver (I) coordination polymers using thioether macrocycle building blocks. Inorg. Chem. 2000, 39, 1035-1038. [CrossRef]

6. Blake, A.J.; Champness, N.R.; Howdle, S.M.; Morley, K.S.; Webb, P.B.; Wilson, C. Silver (I)-thioether coordination polymers constructed using asymmetric diketonate anions. CrystEngComm 2002, 4, 88-92. [CrossRef]

7. Pointillart, F.; Herson, P.; Boubekeur, K.; Train, C. Square-planar and trigonal prismatic silver (I) in bipyrimidine and oxalate bridged tetranuclear complexes and one-dimensional compounds: Synthesis and crystal structures. Inorg. Chim. Acta 2008, 361, 373-379. [CrossRef]

8. Marandi, F.; Ghadermazi, M.; Marandi, A.; Pantenburg, I.; Meyer, G. Two new silver (I) coordination polymers with 4,4'-bipyridine and two perfluoro- $\beta$-diketonates. J. Mol. Struct. 2011, 1006, 136-141. [CrossRef]

9. Jin, J.L.; Xie, Y.P.; Cui, H.; Duan, G.X.; Lu, X.; Mak, T.C. Structure-directing role of phosphonate in the synthesis of high-nuclearity silver (I) sulfide-ethynide-thiolate clusters. Inorg. Chem. 2017, 56, 10412-10417. [CrossRef] [PubMed]

10. Jin, J.L.; Shen, Y.L.; Xie, Y.P.; Lu, X. Silver ethynide clusters constructed with fluorinated $\beta$-diketonate ligands. CrystEngComm 2018, 20, 2036-2042. [CrossRef]

11. Shen, Y.L.; Jin, J.L.; Duan, G.X.; Yu, P.Y.; Xie, Y.P.; Lu, X. Nestlike Silver (I) Thiolate Clusters with Tunable Emission Color Templated by Heteroanions. Chem. A Eur. J. 2021, 27, 1122-1126. [CrossRef]

12. Zanotto, L.; Benetollo, F.; Natali, M.; Rossetto, G.; Zanella, P.; Kaciulis, S.; Mezzi, A. Facile Synthesis and Characterization of New $\beta$-Diketonate Silver Complexes. Single-Crystal Structures of (1,1,1,5,5,5-Hexafluoro-2,4-pentadionato)(2,2'-bipyridine) silver (I) and (1,1,1,5,5,5-Hexafluoro-2,4-pentadionato)(N,N,N', $\mathrm{N}^{\prime}$-tetramethylethylenediamine) silver (I) and Their Use as MOCVD Precursors for Silver Films. Chem. Vapor Depos. 2004, 10, 207-213.

13. Liu, H.; Battiato, S.; Pellegrino, A.L.; Paoli, P.; Rossi, P.; Jiménez, C.; Malandrino, G.; Muñoz-Rojas, D. Deposition of metallic silver coatings by Aerosol Assisted MOCVD using two new silver $\beta$-diketonate adduct metalorganic precursors. Dalton Trans. 2017, 46, 10986-10995. [CrossRef]

14. Piszczek, P.; Radtke, A. Silver nanoparticles fabricated using chemical vapor deposition and atomic layer deposition techniques: Properties, applications and perspectives: Review. In Noble and Precious Metals-Properties, Nanoscale Effects and Applications; Seehra, M.S., Bristow, A.D., Eds.; IntechOpen: London, UK, 2018; pp. 187-213.

15. Ruan, H.X. 1,1,1-(trifluoroacetylacetonato)silver(I) Used for Photochemical and Thermal Deposition of Silver and Silver Oxide Film and Its Kinetics. Master's Thesis, Simon Fraser University, Bumaby, BC, Canada, 2007.

16. Fedoseev, I.S.; Vikulova, E.S.; Il'in, I.Y.; Smolentsev, A.I.; Gallyamov, M.R.; Morozova, N.B. Crystal structure of (1,1,1-trifluoro-5,5dimethylhexan-2,4-dionato) silver (I). J. Struct. Chem. 2016, 57, 1667-1670. [CrossRef]

17. Gulyaev, S.A.; Vikulova, E.S.; Sukhikh, T.S.; Ilyin, I.Y.; Morozova, N.B. Structures and thermal properties of silver (I) $\beta$-diketonates with bulky terminal substituents. J. Struct. Chem. 2021, 62, 1836-1845. [CrossRef]

18. Patterson, S.; Henderson, D.; Tasker, P. CCDC 1410235: Experimental Crystal Structure Determination. 2015. Available online: https:/ / research.utwente.nl/en/publications/ccdc-1483947-experimental-crystal-structure-determination-2 (accessed on 29 December 2021).

19. Xu, C.; Corbitt, T.S.; Hampden-Smith, M.J.; Kodas, T.T.; Duesler, E.N. Synthesis and characterization of Lewis-base adducts of 1,1,1,5,5,5-hexafluoroacetylacetonatosilver (I). J. Chem. Soc. Dalton Trans. 1994, 19, 2841-2849. [CrossRef] 
20. Evans, W.J.; Giarikos, D.G.; Josell, D.; Ziller, J.W. Synthesis and structure of polymeric networks of silver hexafluoroacetylacetonate complexes of THF, toluene, and vinyltrimethylsilane. Inorg. Chem. 2003, 42, 8255-8261. [CrossRef] [PubMed]

21. Akhbari, K.; Morsali, A. One-dimensional Corrugated Tape $\mathrm{Ag}^{\mathrm{I}}$ coordination polymers constructed of $\mathrm{Ag}-\mathrm{C}$ bonds. Cryst. Growth Des. 2007, 7, 2024-2030. [CrossRef]

22. Rybaltovskii, A.O.; Arakcheev, V.G.; Bekin, A.N.; Danilyuk, A.F.; Gerasimova, V.I.; Minaev, N.V.; Golubeva, E.N.; Parenago, O.O.; Bagratashvili, V.N. Photo-induced processes in Ag and Eu $\beta$-diketonates incorporated into aerogel matrix of silicon dioxide by supercritical fluid impregnation. Russ. J. Phys. Chem. B 2015, 9, 1137-1142. [CrossRef]

23. Wisser, F.M.; Schumm, B.; Mondin, G.; Grothe, J.; Kaskel, S. Precursor strategies for metallic nano-and micropatterns using soft lithography. J. Mater. Chem. C 2015, 3, 2717-2731. [CrossRef]

24. Calabrese, G.; Petralia, S.; Franco, D.; Nocito, G.; Fabbi, C.; Forte, L.; Guglielmino, S.; Squarzoni, S.; Train, F.; Conoci, S. A new Ag-nanostructured hydroxyapatite porous scaffold: Antibacterial effect and cytotoxicity study. Mater. Sci. Eng. C 2021, 118, 111394. [CrossRef] [PubMed]

25. Pettinari, C.; Pettinari, R.; Di Nicola, C.; Tombesi, A.; Scuri, S.; Marchetti, F. Antimicrobial MOFs. Coord. Chem. Rev. 2021, 446, 214121. [CrossRef]

26. Jaros, S.W.; Krogul-Sobczak, A.; Bażanów, B.; Florek, M.; Poradowski, D.; Nesterov, D.S.; Śliwińska-Hill, U.; Kirillov, A.M.; Smoleński, P. Self-assembly and multifaceted bioactivity of a silver (I) quinolinate coordination polymer. Inorg. Chem. 2021, 60, 15435-15444. [CrossRef]

27. Fernandes, T.A.; Costa, I.F.; Jorge, P.; Sousa, A.C.; André, V.; Cerca, N.; Kirillov, A.M. Silver (I) coordination polymers immobilized into biopolymer films for antimicrobial applications. ACS Appl. Mater. Interfaces 2021, 13, 12836-12844. [CrossRef] [PubMed]

28. Mikhailovskaya, T.F.; Makarov, A.G.; Selikhova, N.Y.; Makarov, A.Y.; Pritchina, E.A.; Bagryanskaya, I.Y.; Vorontsova, E.V.; Ivanov, I.G.; Tikhova, V.D.; Gritsan, N.P.; et al. Carbocyclic functionalization of quinoxalines, their chalcogen congeners 2,1,3benzothia/selenadiazoles, and related 1,2-diaminobenzenes based on nucleophilic substitution of fluorine. J. Fluor. Chem. 2016, 183, 44-58. [CrossRef]

29. Fulmer, G.R.; Miller, A.J.; Sherden, N.H.; Gottlieb, H.E.; Nudelman, A.; Stoltz, B.M.; Bercaw, J.E.; Goldberg, K.I. NMR Chemical Shifts of Trace Organics and Impurities: Common Laboratory Solvents and Gases in Deuterated Solvents Relevant to the Organometallic Chemist. Organometallics 2010, 29, 2176-2179. [CrossRef]

30. Li, T.; Gamer, M.T.; Scheer, M.; Konchenko, S.N.; Roesky, P.W. Intramolecular Phosphorus-Phosphorus Bond Formation within a $\mathrm{Co}_{2} \mathrm{P}_{4}$ Core. Chem. Comm. 2013, 49, 2183-2185. [CrossRef]

31. Sheldrick, G.M. SHELXT-Integrated space-group and crystal-structure determination. Acta Cryst. A 2015, 71, 3-8. [CrossRef]

32. Sheldrick, G.M. Crystal structure refinement with SHELXL. Acta Cryst. C 2015, 71, 3-8. [CrossRef]

33. Dolomanov, O.V.; Bourhis, L.J.; Gildea, R.J.; Howard, J.A.K.; Puschmann, H. OLEX2: A complete structure solution, refinement and analysis program. J. Appl. Cryst. 2009, 42, 339-341. [CrossRef]

34. Alvarez, S.; Alemany, P.; Casanova, D.; Cirera, J.; Llunell, M.; Avnir, D. Shape maps and polyhedral interconversion paths in transition metal chemistry. Coord. Chem. Rev. 2005, 249, 1693-1708. [CrossRef]

35. Powder Diffraction File, Release 2010, International Centre for Diffraction Data, Pennsylvania, USA. Available online: http:/ / www.icdd.com/products/pdf2.htm (accessed on 20 December 2021). 